\title{
Cold seeps along the main Marmara Fault in the Sea of Marmara (Turkey)
}

\author{
T.A.C. Zitter ${ }^{a}{ }^{*}$, P. Henry ${ }^{a}$, G. Aloisi ${ }^{b}$, G. Delaygue ${ }^{a}$, M.N. Çagatay $^{c}$, B. Mercier de Lepinay ${ }^{d}$, \\ M. Al-Samir ${ }^{\mathrm{e}}$, F. Fornacciari ${ }^{\mathrm{a}}$, T.M. Tesmer ${ }^{\mathrm{e}}$, A. Pekdeger $^{\mathrm{e}}$, K. Wallmann $^{f}$ and G. Lericolais ${ }^{\mathrm{g}}$ \\ ${ }^{a}$ CEREGE, Aix-Marseille Université, CNRS/INSU, IRD, Collège de France, Chaire de Géodynamique, Europôle \\ de l'Arbois, Bat. Trocadéro, BP80, 13545 Aix-en-Provence Cedex 04, France \\ ${ }^{\mathrm{b}}$ PEPS, Université de Lyon 3, CNRS/INSU, Lyon, France \\ c Istanbul Technical University, Istanbul, Turkey \\ d Géosciences Azur, Université de Nice, CNRS/INSU, IRD, Nice, France \\ ${ }^{\mathrm{e}}$ Free University of Berlin, Berlin, Germany \\ ${ }^{f}$ GEOMAR, Research Center for Marine Geosciences, Kiel, Germany \\ ${ }^{\mathrm{g}}$ IFREMER, French Research Institute for Exploitation of the Sea, Brest, France
}

*: Corresponding author : Zitter T., email address : zitter@cerege.fr

\begin{abstract}
:
The main Marmara Fault exhibits numerous sites of fluid venting, observed during previous cruises and in particular with R.O.V. VICTOR during the MARMARASCARPS cruise (2002). Long CALYPSO cores were recovered near active vents and at reference sites during the MARMARA-VT cruise (2004), together with echosounder sub-bottom profiles (frequency of $3.5 \mathrm{kHz}$ ). We compiled R.O.V. video observations from MARMARASCARPS cruise and show that all known seeps occur in relationship with strike-slip faults, providing pathways for fluid migration. Among the main active sites, a distinction is made between gas seeps and water seeps. At gas seeps, bubble emissions at the seafloor or disturbed echofacies on sounder profiles demonstrate the presence of free methane gas at a shallow depth within the sediment. Most cores displayed gas-related expansion, most intense for cores taken within the gas plumes. On the other hand, authigenic carbonate chimneys characterize the water seeps and visible water outflow was observed at two sites (in the Tekirdağ and Central basins). The pore fluid chemistry data show that the water expelled at these sites is brackish water trapped in the sediment during lacustrine times (before $14 \mathrm{cal} \mathrm{kyr}$ BP), in relation with the paleoceanography in the Sea of Marmara. The chimney site in the Tekirdağ Basin is located at the outlet of a canyon feeding a buried fan with coarse sandy turbidites. Pore fluid composition profiles indicate that the sand layers channel the brackish fluids laterally from the basin into the fault zone at less than $20 \mathrm{~m}$ depth. However, a deeper gas source cannot be excluded.
\end{abstract}

Keywords: Sea of Marmara; Cold seeps; Seafloor observations; Fault scarp; High permeability pathways

\section{Introduction}

Seafloor manifestations of fluid expulsion are common on continental shelves and slopes worldwide and are designated as cold seeps (Paull, 1984; Juniper and Sibuet, 1987; Dimitrov and Woodside, 2003; Judd and Hovland, 2007). Cold seeps are often observed in association with active faults (Moore et al., 1990, Le Pichon at al., 1992; Henry et al., 2002 ), leading to the hypothesis that at least some of these faults may channel fluids from deep levels in the sediment and possibly from the seismogenic zone in the crust. Although cold seeps are 
frequently associated with compression, strike-slip faults appear favourable for the expulsion of deep fluids (Orange et al., 1999; Chamot-Rooke et al., 2005; Zitter et al., 2006).

The Sea of Marmara is located on the northern branch of the North Anatolian Fault. This major system takes up about 20 to $25 \mathrm{~mm} / \mathrm{yr}$ of strike-slip motion, representing most of the motion between the Anatolian plate and the Eurasian plate (Fig. 1; McClusky et al., 2000; Armijo et al., 2002 ; Meade et al., 2002; Le Pichon et al., 2003). The seafloor expression of active faults in the Sea of Marmara is known from EM300 multibeam bathymetric surveys, high-resolution seismics, and video observations (Imren et al., 2001; Rangin et al., 2001, 2004; Armijo et al., 2002, 2005; Demirbag et al., 2003; Beck et al., 2007). Although tectonic interpretations may differ regarding the amount of extension taken up by individual faults, published seafloor fault maps are comparable (Fig. 2), except along the southern edge of the Çınarcık Basin.

Following the 1999 Kocaeli earthquake, gas release into the water column of the Gulf of Izmit was observed (Alpar, 1999) and gas migration within the sediments was imaged with high resolution seismics (Kuscu et al., 2005). In the main part of the Sea of Marmara, cold seeps were observed with deep-towed cameras and dissolved methane anomalies were found in the water column (Pätzold et al., 2000). Remotely-operated vehicle (ROV) dives along active fault scarps later showed carbonate chimneys with visible water outflow (Armijo et al., 2005); this latter observation is rather unusual for cold seeps.

This study focuses on identifying the geological controls on cold seep pattern and distribution. We rely on ROV VICTOR visual observations from MARMARASCARPS (Armijo et al., 2005) to identify and map seafloor manifestations. At several locations, the presence of gas in the sediment can be established from chirp sub-bottom profiler and observations on cores. The relationship between cold seeps and active faults is assessed based on these observations and on previous morphotectonic studies (Fig. 2; Imren et al., 2001; Rangin et al., 2001, 2004; 
Armijo et al., 2002, 2005; Demirbag et al., 2003; Beck et al., 2007). During MARMARAVT/MARMACORE2 cruise in 2004, four cores were taken in different settings (water outflow zone, gassy sediment zone and reference site) for pore fluid extraction (cruise report, cruise data and core description are available at http://cdf.u-3mrs.fr/ henry/marmara). Fluidsediment interactions at depth affecting fluid chemistry, the chemical composition of the expelled fluids reflects not only their origin, but also the processes during their ascent. It is thus expected that the pore fluid composition should provide useful information on the source and flow paths of the fluids. We present here elemental pore fluid composition, chlorinity, and sulfate data from these cores. These data show that the water expelled is of very low salinity and we examine possible explanations. We also show that the characteristics of the fluid seepages are not entirely defined by tectonics, but also influenced by sedimentary structure (e.g. sand layer geometry) and erosion.

\section{Material and Methods}

The data presented in this paper were acquired during two different cruises. The MARMARASCARPS cruise took place on board the R/V L'ATALANTE from 16 September to 15 October 2002 and provided chirp subbottom profiler data and ROV survey for microbathymetry and visual observations of the seafloor. Underwater navigation was processed with IFREMER ADELIE software $\subset$. We compiled video observations and seafloor pictures from the ROV VICTOR6000 and localized different manifestations of seafloor venting using ARCGIS/ADELIE software. The area of observation depends on the altitude of the ROV, but in general is 2-3 m wide and several meters deep. Most images resolve objects of centimeter-scale in size. Microbathymetry data were displayed with Generic Mapping Tool (Wessel and Smith, 1991), with grid cell size 0.5 x 0.5 m. 
The MARMARA-VT cruise took place on board the R/V MARION DUFRESNE from 4 May to 8 May 2004 and operated the giant Calypso piston corer that retrieves up to $55 \mathrm{~m}$ long cores. Cores MD04-2737, MD04-2740, MD04-2741 and MD04-2742 cores (Tab. 1; Fig. 2) were retrieved between 592 to 1245 m water depth, for MARMARA-VT purpose; core lengths range between 24.47 and $41.85 \mathrm{~m}$. Sediment sampling for pore fluid extraction was performed at section ends while the cores were cut in $1.5 \mathrm{~m}$ long sections on the deck, immediately after recovery. Additional samples were taken later on split sections to improve resolution (20 $\mathrm{cm}$ to $50 \mathrm{~cm}$ resolution) in the first few meters. Samples were wrapped in parafilm to prevent evaporation and stored in a cold room before pore fluid extraction. They were then squeezed at $4^{\circ} \mathrm{C}$ in the cold room with a pore water squeezer, using an argon pressure of $0.35 \mathrm{MPa}$, through a cellulose membrane filter of $0.2 \mu \mathrm{m}$. Pore water squeezers used onboard were provided by ITU and by GEOMAR. They can process batches of up to 10 samples. Volumes extracted decreased with depth but volumes of 5 to $25 \mathrm{ml}$ could be extracted. Carbonate alkalinity and $\mathrm{pH}$ were measured on board but all other measurements were performed in shore based laboratories. Elemental concentrations (B, Li, $\mathrm{Mn}, \mathrm{Ca}, \mathrm{Fe}, \mathrm{Na}$, Mg, Sr, Si, Ba, K) were determined with ICP-AES (Inductively Coupled Plasma Atomic Emission Spectroscopy) at IFM-GEOMAR and are given in Table 2 with standard deviations. Chloride and sulfate were determined using a colorimetric method with a Technikon@ segmented-flow autoanalyzer and have a precision of $1.5 \mathrm{mmol} / \mathrm{L}$. Chirp sub-bottom profiler data were also acquired during this cruise.

\section{Cold seeps in the Sea of Marmara}

\subsection{Cold seep characteristics and background}


The seafloor manifestations in the Sea of Marmara have many characteristics in common with other cold seep sites around the world observed in previous studies (Henry et al., 1996, 2002; Sibuet and Olu, 1998; Dimitrov, 2003; Hovland, 2003; Zitter et al., 2005; Judd and Hovland, 2007). Cold seeps are areas where seepage of fluids enriched in reduced compounds, most commonly methane and hydrogen sulfide, occurs through the seafloor. These compounds may be dissolved in the pore fluid or they may migrate as a separate gas phase. Manifestations of redox reactions such as dark patches are an indirect indication of fluid expulsion through the seafloor. The bottom water of the Sea of Marmara has low oxygen content but is not anoxic. In normal conditions, deep sea sedimented seafloor is grey to brown with animals burrows and sulfate reduction occurs a few meters deep within the sediment (Çagatay et al., 2004). In dark patches sulfate reduction occurs immediately beneath the seafloor surface (Tsunogai et al., 2002). The dark color of the sediment presumably results from the accumulation of iron sulfides, sometimes combined with organic matter. Dark patches are often covered with white mats with little apparent structure. These patches are attributed to sulfide oxidizing bacteria (Sassen et al., 1993) and develop where sulfide flux through the seafloor is high. Bacterial mats are also the first colonisers of new seeps or new surfaces (Hovland, 2002; Teichert et al., 2005).

Cold seeps induce an increase of benthic biological activity (Paull et al., 1984; Sibuet et al., 1988; Olu et al., 1996; Sibuet and Olu, 1998). Some of the species found in this environment (e.g. bivalves and siboglinids polychaetes) bear symbiotic bacteria using methane or sulfide oxidation as their primary energy source. Other species abundant at cold seeps have no proven symbiotic association and some of them are mere opportunists (e.g. tubicolous polychaetes, gastropods, galatheid crabs, echinoderms, macrurid fishes). The Sea of Marmara fauna shares some characteristics with that of the Mediterranean (Olu-Le Roy et al., 2004), but unlike in the Mediterranean, no siboglinids polychaetes have been observed yet. One 
remarkable feature is the abundance of dead sea urchins near, and in, the black patches, where they lie partially buried. They have not been identified yet, but they appear to belong to species of spineless urchins living burrowed into the sediments.

Authigenic carbonate crusts precipitated at the sediment/water interface and carbonate chimneys are common at cold seep sites and are considered to be by-products of the microbial oxidation of hydrocarbons (Kulm et al., 1986; Hovland et al., 1987; Kulm and Suess, 1990; Von Rad et al., 1996; Aloisi et al., 2000). Inactive chimneys could be eroded remnants of conduits which formed within the sediment. However, there are occurences of active chimneys, or chemoherms which formed at least in part above the seafloor (Teichert et al., 2005). Spectacular examples are found in the Black Sea, where their growth in the bottom water is probably favored by anoxic conditions (Michaelis et al., 2002).

Methane emission in the water column can be detected from dissolved gas content (Charlou et al., 2003) or from geophysics when gas bubbles are expelled (Alpar, 1999; Kuscu et al., 2005). A strong increase of spontaneous bubble emission was observed in the Gulf of Izmit after the Kocaeli 1999 earthquake (Alpar, 1999; Kuscu et al., 2005). In the main part of the Sea of Marmara, dissolved gas was detected (Pätzold et al., 2000). During MARMARASCARPS cruise, gas bubble escaped from black patches when small corers where pushed into the sediment, as shown in the supplementary movie provided by Armijo et al. (2005).

\subsection{ROV Observations in the Sea of Marmara}

The physiography of the Sea of Marmara consists of two distinct areas: a wide southern shelf (about $30 \mathrm{~km}$ from shoreline to $100 \mathrm{~m}$ contour) and a northern area where lies a series of E-W trending basins (up to $1200 \mathrm{~m}$ in depth) separated by NNE-SSW trending ridges (Fig. 1). The fault trace, visible in the EM300 bathymetry is well expressed across the highs but has a more 
complex pattern within the basins (Fig.2). We will describe seafloor manifestations of fluid seepage from west to east, across the Tekirdağ Basin, the Western High, the Central Basin, and the Çınarcık Basin.

\subsubsection{Tekirdă Basin}

In the Tekirdağ Basin, all known seeps are observed along the main fault scarp on the southern side of the basin. This fault is connected to the Ganos fault with a $10^{\circ}$ clockwise bend (Fig. 2). The fault trace may be followed based on bathymetry and microbathymetry. Clusters of black patches and bacterial mats are found sporadically (with typical spacing 2 $\mathrm{km}$ ) along the western part of the fault trace, where no seafloor rupture was observed with the ROV (Fig.3). Seepage activity increases eastward, to become nearly continuous.

The most remarkable site is a $400 \mathrm{~m}$ wide zone located at the outlet of a canyon where a seafloor rupture with horizontal slickenslides was found (Armijo et al., 2005). It comprises seven main carbonate chimneys (T1 to T7 from W to E, Fig. 4), forming conical, cylindrical or mound-shaped constructions 10 to $50 \mathrm{~cm}$ high. Their summits are covered with white material which is most probably bacterial mat, or may consist of mineral precipitates (such as metal sulfides). At the $100-400 \mathrm{~m}$ scale, chimneys align along the $\mathrm{N} 80^{\circ}$ main $1-2 \mathrm{~m}$ high fault scarp (Fig. 4). At the 1-50 m scale, alignments striking N65 were also observed at several sites and are interpreted as R1 Riedel shears. The chimneys T2, T3, T4 and T7 occur at the intersection of the main $\mathrm{N} 80^{\circ}$ fault scarp and $\mathrm{N} 65^{\circ}$ - striking carbonate outcrops. The chimneys $\mathrm{T} 5$ and $\mathrm{T} 6$ lie along a $\mathrm{N}^{\circ} 5^{\circ}$ trend also comprising smaller vents (at least 6). These smaller vents (T6b to T6g) bear bacterial mats and are spaced at 1-3 m intervals. They form the most active site of the area. Chimney T6a (also known as "Jack the Smoker"; Armijo et al., 2005) is a conical active chimney $50 \mathrm{~cm}$ wide at the base, and $50 \mathrm{~cm}$ high. The peak is covered by white and brown bacterial mat and small yellow bivalves are found on the 
flank of the chimney. An outflow of fresh water, visible by a difference of optical index from the surrounding seawater, is escaping from a fissure near the top. Seeping of water also occurs from numerous vent orifices at the base of the chimney. Near Jack the smoker, two small peaks crowned with bacterial mats of 10 and $30 \mathrm{~cm}$ high (T6b and T5) are found within small dark patches within a distance of less than $1 \mathrm{~m}$. The chimney T4 is found on the edge of a carbonate slab, which presumably redirects the flow. T3 is found on top of a stratified carbonate pile and now appears inactive, while seeping occurs in a depression surrounding the mound, as shown by the distribution of bivalves and bacterial mats. At Site T2, authigenic carbonate crusts were broken result of seafloor displacement of up to $1 \mathrm{~m}$ of vertical offset (Fig. 9a in Armijo et al., 2005; Fig. 5) and this rupture exposes parts of the plumbing system, which would normally be buried in the sediment. Chimney T2 lies on the seafloor rupture and $2 \mathrm{~m}$ east of T2, a carbonate chimney built on top of the scarp was broken by the fault rupture and displays its internal structure (Fig. 5).

The distribution of vents at the main Tekirdağ site shows that focussed flow occurs along fault conduits and that interaction between Riedel faults and the main fault plane appears favourable to conduit formation. Observations also suggest that sealing of conduits by authigenic carbonate competes with erosion and fracturing.

\subsubsection{Western High}

On the Western High, ROV visual observations extend for $5 \mathrm{~km}$ along the fault within a small pull-apart basin (Fig. 3). Venting sites are revealed by clusters of black circular patches, occasionally associated with bacterial mats. In the most active zone black patches align continuously over $250 \mathrm{~m}$ along the fault. There are few occurrences of carbonate crusts: small concretions, less than $10 \mathrm{~cm}$ wide, are observed at two sites. Within one of the black patches, bubbles escaped from the sediment while a push core was taken with the ROV, indicating the 
presence of free gas immediately beneath the seafloor (Supplementary on-line material, Armijo et al., 2005).

\subsubsection{Central Basin}

In the Central Basin, two nested fault systems were observed. An inner rhombus-shaped connects to the strike slip faults on topographic highs on either side (Le Pichon et al., 2001; Rangin et al., 2004). Additional faults follow the base of the northern and southern slopes (Armijo et al., 2002). The northern fault branches from the Central High strike-slip fault, while the southern fault branches from the Western High strike-slip fault. The nature and level of activity of these external faults is debated (Rangin et al., 2004). Based on morphology and $3.5 \mathrm{kHz}$ profiles from MARMARASCARPS cruise, we consider that the northern branch has recent (post 17000 years) motion, likely with a combination of strike-slip and normal motion.

The ROV visual observation tracks follow the southern scarp in the middle of the basin and the base of the slope along the northern fault branch. Venting sites are present along both fault scarps. However, they are scarce and of limited extent. In the middle of the basin, noteworthy seepage occurs close to a zone where gas was suspected within the sediment from an acoustic anomaly in the $3.5 \mathrm{kHz}$ data (see section 4). In this area, seafloor exhibits carbonate crust pavements, black patches and brown and white bacterial mat. Another seepage zone, which is presently inactive, is located at the connection with the strike-slip fault on the western topographic high. Crust pavements outcrop from place to place on the seafloor. Along the northern scarp, the vent sites are generally zones of small black patches about $20 \mathrm{~cm}$ wide (Fig. 7a) separated a few hundreds of meters from each other (250, 300 and $500 \mathrm{~m}$ ). The most active zone is located at the northeastern end of the basin where the fault scarp intersects the outlet of a canyon. Carbonate crust pavement is found across several hundreds of meters 
(about $300 \mathrm{~m}$ ). At the top of the slope, the $20 \mathrm{~cm}$ thick carbonate slabs are completely covered by hemipelagic sediments, and outcrop along $\mathrm{N} 90^{\circ}$ elongated zones of black reduced sediments, with from place to place sea anemones and sea urchins. Farther downslope, and especially along the slope break, the carbonate crusts form about $1 \mathrm{~m}$ wide chaotic broken slabs. In some places, the carbonate slabs are piled up on each other forming up to 1 to $2 \mathrm{~m}$ high outcrops (Fig. 7b). Two small carbonate chimneys (C1 and C2) about $10 \mathrm{~cm}$ high are observed in this area covered with white and brown sulfide oxidizing bacterial mat (Fig. 7c and 7d). Along the same bathymetric scarp, $150 \mathrm{~m}$ eastward, an isolated $3 \mathrm{~m}$ high anthillshaped carbonate mound, dusted with hemipelagic sediments indicates a dead zone (Fig. 7e). About $1 \mathrm{~km}$ eastward, another zone with small carbonate crusts covered with a very thin veneer of hemipelagic sediment is observed.

\subsection{4. Çınarcık Basin}

The southern side of the Çınarcık Basin was poorly explored. Visual observations only occurred from place to place (Fig. 8) along some linear scarps corresponding to outcrops of sedimentary strata. No seepage was observed on this side of the basin. On the northern side of the basin, visual observations were made along the fault scarp that outlines the base of the slope and where fluid vents were observed. They are scarce and consist of isolated black patches of reduced sediments a few tens of centimeters in diameter, sometimes associated with bacterial mats, or with bacterial mats directly at the surface of the sediment (Fig. 8). Bivalves and sea anemones are also present. They sometimes form clusters of localized vents about $200 \mathrm{~m}$ apart. The easternmost seeping area, localized around (N4046, E29 $\left.{ }^{\circ} 11\right)$, is found next to a slump scar and is composed of two vents sites $250 \mathrm{~m}$ apart with several black patches on the seafloor. 


\section{Sediment and pore fluids}

\subsection{Geophysical observations}

In the basins, $3.5 \mathrm{kHz}$ chirp profiles are generally of good quality, locally showing acoustic disturbance caused by gas, mainly acoustic blanking and acoustic turbidity. Acoustic blanking is characterized by a transparent domain in the seismic section. Vertical acoustic blanking is mainly interpreted as the result of the attenuation of the acoustic signal caused by the gas within the sediments, while transparent acoustic layers are most commonly interpreted as debris flows processes or under-compacted clay-rich sediments (Papatheodoru et al., 1993; Bouriak et al., 2000). Acoustic turbidity characterizes zones of disturbance of the seismic record, with noisy and discontinuous reflections. This feature may be attributed to the presence of gas bubbles within the sediments, or to a disturbed sedimentary structure, such as coarser poorly sorted sediments scattering the acoustic signal (Hovland and Judd, 1988).

We present here two examples of such acoustic anomalies in the seismic records that are associated with seafloor seepage manifestations. In the Central basin, a zone of acoustic blanking is found on the footwall of the main fault scarp, adjacent to an active seepage site, and can be observed on both WNW-ESE and N-S chirp profiles (Fig. 6 and 9). This zone shows a vertical mushroom-shaped blanking area about $200 \mathrm{~m}$ wide topped with an enhanced reflector found 14 ms TWT (two way travel time) below seafloor (about $11 \mathrm{~m}$ assuming a sound velocity in the sediments of $1600 \mathrm{~m} / \mathrm{s}$ ) (Fig. 9a and b). This acoustic blanking zone is interpreted as gas-charged sediments, and core MD04-2742 was retrieved within this anomaly. The WNW-ESE chirp profile parallel to the scarp also crosses farther west another blanking zone about $70 \mathrm{~m}$ wide topped with an enhanced reflector (Fig. 9a).

In the Tekirdağ Basin, a zone of acoustic turbidity is widespread on the northern slope (Fig. 10). The top of this acoustically turbid zone corresponds to the top of the lacustrine 
sediments. A smaller zone is observed in the SE of the basin near the carbonate chimneys site and two cores were retrieved within this area (Fig.11). This zone is observed on several chirp profiles, covering an area of $1.5 \times 2.5 \mathrm{~km}$ at the outlet of the canyon, and could be attributed to the presence of gas within the sediments or to coarser sand bodies from the canyon, or to a combination of both. An unconformity underlain by strong reflectors beneath is found at about $40 \mathrm{~ms}$ TWT and presumably reflects a change in sedimentary input after the marinelacustrine transition. However, the canyon and levee structure observed on one profile suggests the canyon is still active.

\section{2 Observations on Cores}

During the MARMARA-VT cruise in 2004, long sediment cores were taken at the sites where free gas was suspected in the Tekirdağ Basin (MD04-2737 and MD04-2740) and Central Basin (MD04-2742). These cores may be compared with cores taken during the same cruise on the basement highs (MD04-2741), and also in the same basins during MARMARACORE cruise (Beck et al., 2007). All cores displayed gas expansion and gas voids and it was often necessary to drill holes through the core liner to release excess pressure before cutting. This behaviour does not necessarily imply that free gas is present in situ as gas pressure in the core liner may result from degassing of methane originally dissolved in the pore fluid. However cores taken in the suspected gas plumes had voids up to $2.5 \mathrm{~m}$ (for core MD04-2737), and some sections were filled with a mixture of liquid mud and gas which erupted violently through the holes drilled in the core liner. Total amount of gas expansion reached $670 \mathrm{~cm}$ in core MD04-2737, $455 \mathrm{~cm}$ in core MD04-2742 and $180 \mathrm{~cm}$ in core MD04-2741. The biggest voids are found in core MD04-2737 with voids of $104 \mathrm{~cm}$ at $11 \mathrm{~m}$ BSF (below seafloor) and of $253 \mathrm{~cm}$ (more than one empty section) at $36 \mathrm{~m} \mathrm{BSF}$, and in core MD04-2742 with void of $92 \mathrm{~cm}$ at $10 \mathrm{~m}$ BSF. Core MD04-2741 shows gas expansion between 10 and $18 \mathrm{~m}$ BSF. 
Also remarkable is the presence of thick layers of coarse sands in the Tekirdağ Basin at a depth in core corresponding to the strong reflectors beneath the unconfomity in the $3.5 \mathrm{kHz}$ profile (Fig. 11). These sands are rich in various shells and shell fragments, and contain Dreissena bivalves or Turricaspia shells. This observation does not imply that lacustrine conditions prevailed at the time of sand deposition as the shells could be reworked, but shows a stronger input of coarse material from the canyon at the time of the lacustrine-marine transition. A $1 \mathrm{~m}$ thick sand layer was recovered in core MD04-2737 at $40 \mathrm{~m}$ depth in core. Closer to the canyon outlet, core MD04-2740 sampled $10 \mathrm{~m}$ of sand at its base (beneath $12 \mathrm{~m}$ BSF), but this may not reflect in situ thickness because fluidisation is possible during coring. However, the onlaps on the $3.5 \mathrm{kHz}$ profile do suggest that discrete sand layers in the basin coalesce near the canyon outlet where they reach the fault zone.

\subsection{Pore fluid geochemistry}

The chloride concentration in cores is nearly constant in the first 5 to $10 \mathrm{~m}$ (depending on the core) and decreases progressively with depth below (Fig. 12 and Tab. 2). Elements Na, Mg, K, and B display similar behaviour. Cross plots of $\mathrm{Na}, \mathrm{Mg}$ and $\mathrm{B}$ versus $\mathrm{Cl}$, are shown on figure 13. On these plots, Core MD04-2740 data follow linear trends. This observation suggests a simple mixing between fluids in the surface layer and in the sand layer found at 12 $\mathrm{m}$ depth in core. End-member fluids on this mixing line are the Sea of Marmara deep water and a low salinity end-member. The composition of the low salinity end-member along the mixing trend is bracketed in the following way: (1) The maximum possible concentration in $\mathrm{Cl}, \mathrm{Na}, \mathrm{Mg}$ and $\mathrm{B}$ is defined by the deepest sample; (2) The minimum chloride concentration of $100 \mathrm{mmol} / \mathrm{L}$ is inferred extrapolating the boron versus chloride trend for MD04-2740 to a $0 \mathrm{mmol} / \mathrm{L}$ boron concentration. Possible low salinity end-member fluid compositions thus range $0-70 \mu \mathrm{M}$ for boron, $100-200 \mathrm{mmol} / \mathrm{L}$ for chloride, $40-120 \mathrm{mmol} / \mathrm{L}$ for sodium, 8-18 
$\mathrm{mmol} / \mathrm{L}$ for magnesium, and 0.6-2.4 mmol/L for potassium. Concentrations of $\mathrm{Cl}, \mathrm{Na}, \mathrm{Mg}, \mathrm{K}$, and B in other cores are consistent with the mixing line defined by MD04-2740, although Mg, $\mathrm{K}$ and $\mathrm{B}$ data display some deviations, which may be explained by in situ reactions within the sediment. Other elements (Ca, $\mathrm{Li}, \mathrm{Sr}, \mathrm{Ba}, \mathrm{Mn}, \mathrm{Fe}, \mathrm{Si}$ ) do not follow mixing lines, most likely because the concentrations of these elements are more influenced by in situ reactions (Tab. 2). Sulfate concentration drops to near zero value as soon as chlorinity starts to decrease (5 to 10 m BSF). As may be expected, barium (see Tab. 2) increases sharply at the same level due to the dissolution of barium sulphate $\left(\mathrm{BaSO}_{4}\right)$. The sulfate-chloride cross plot indicates thus a correlation between the sulfate-methane reaction zone, generally observed at a few meters below seafloor in the Sea of Marmara (Halbach et al., 2004; Çagatay et al., 2004) and the chlorinity decrease. This correlation is observed in all cores and is not specific to seepage sites. Anaerobic methane generation may thus occur within the sediment at a depth of only a few meters throughout the Sea of Marmara.

We have seen that fluid composition plots of $\mathrm{Cl}$ versus B, Na and Mg (Fig. 13) suggest mixing between a seawater end-member and a low-salinity end-member. It is well known from previous paleoenvironnemental studies that the Sea of Marmara underwent a lacustrine episode prior to the last glacio-eustatic sea level rise in late Quaternary time (Aksu et al., 1999; Çagatay et al., 2000; Çagatay et al., 2003; Ryan et al., 2003) and that the lacustrine to marine transition occurred at about 14 kyr BP Cal (12 Kyr BP ${ }^{14}$ C; Çagatay et al., 2000). In this context, we propose that the burial of fresh or brackish water is the main cause of pore water freshening with depth. The low-salinity end-member composition suggests that the Marmara Lake retained some salt (at least $100 \mathrm{mM} \mathrm{Cl}$ ). However, the end-member fluid has been altered by reactions in the sediment, such as sulfate reduction, and consequently is probably different from the original composition of the Marmara Lake. 
Theoretically, pore water freshening may be produced by a variety of other mechanisms (Martin et al., 1996; De Lange and Brumsack, 1998; Brown et al., 2001; Kopf and Deyhle, 2002). Among them, upward migration of pore fluid from the zone of smectite to illite reaction and gas hydrates dissociation may be hypothesized in the Sea of Marmara. However, a high temperature diagenetic fluid source, compatible with smectite dehydration taking place at temperatures ranging from about $60{ }^{\circ} \mathrm{C}$ to about $150{ }^{\circ} \mathrm{C}$, is expected to be enriched in B and Li with respect to seawater (You et al. 1993; Kopf and Deyhle, 2002). This observation is not supported by our data (Tab. 2 and Fig. 13), showing low B and Li, and indicating thus low temperature reactions. The hydrate freshening hypothesis is also unlikely. The minimum temperature recorded in the deep water is $14.4^{\circ} \mathrm{C}$ (for a salinity of 38) and the minimum depth for hydrate stability under these conditions is $1350 \mathrm{~m}$ (Henry et al., 1999). As the maximum depth of the Sea of Marmara is $1260 \mathrm{~m}$, this excludes the presence of pure methane hydrate. It would still be possible to form hydrates from gas mixtures involving methane and higher hydrocarbon or $\mathrm{H}_{2} \mathrm{~S}$, but these are unlikely to be widespread, while freshening is observed systematically both in basins and on topographic highs.

Following these arguments, we assume that the progressive decrease of $\mathrm{Cl}$ concentration with depth is the result of diffusion between the present day seawater and a low salinity pore fluid equilibrated with Marmara Lake water during the glaciation. The nearly constant chloride concentration in the first 5 to $10 \mathrm{~m}$ and the coincidence of this level with the sulfate-methane reaction zone requires a non-local mixing process (Wallmann et al., 1997). Investigating the cause of mixing is not within the objectives of this work. We will only assume that some process homogenizes pore fluid composition to a depth $\mathrm{z}_{0}$ in the sediment and that $\mathrm{z}_{0}$ does not vary significantly with time. In the absence of advection flux (pure diffusion), the chlorinity profile below this level may be approximated as an error function (Crank, 1975). 


$$
\left[\mathrm{Cl}^{-}\right]=\left[\mathrm{Cl}^{-}\right]_{\text {lake }}+\left(\left[\mathrm{Cl}^{-}\right]_{\text {sea }}-\left[\mathrm{Cl}^{-}\right]_{\text {lake }}\right) \cdot \operatorname{erfc}\left(\frac{\mathrm{z}-\mathrm{z}_{0}}{2 \sqrt{\mathrm{Dt}}}\right)
$$

In Fig. 12, model 1 is an example of diffusion profile shown for an instantaneous salinization at 14000 years B.P. of a freshwater lake $\left(\left[\mathrm{Cl}^{-}\right]_{\text {lake }}=0\right)$ with present day seawater $\left(\left[\mathrm{Cl}^{-}\right]_{\text {sea }}=\right.$ $600 \mathrm{mmol} / \mathrm{L}$; appropriate for bottom water in the Sea of Marmara), and a diffusion coefficient for chloride in the sediment $\mathrm{D}=10^{-9} \mathrm{~m}^{2} \mathrm{~s}^{-1}$, corresponding to a temperature of $14^{\circ} \mathrm{C}$ and a formation factor of 2 (Li and Gregory, 1974; Henry et al., 1996). However, the true salinity of the lake is probably non-zero and model 2 is presented for an initial $\left[\mathrm{Cl}^{-}\right]_{\text {lake }}=100 \mathrm{mmol} / \mathrm{L}$. These theoretical profiles should be considered as reference curves representing the noadvection state, and not as fitted profiles. Profiles from core MD04-2741 on the Western High and from core MD04-2742 on the Central Basin lie on either side of the reference curves and display comparable average gradients $(13 \mathrm{mmol} / \mathrm{L} / \mathrm{m})$. Likely, these profiles do not require advection and may be fitted with more elaborate models for salinization and surface layer mixing. Remarkably, MD04-2742 is located in a gassy sediment column. The absence of significant water advection at this site indicates that gas and water may not always migrate together or along the same paths. In the Tekirdağ Basin, the chlorinity gradient at MD04-2737 is only $7 \mathrm{mmol} / \mathrm{L} / \mathrm{m}$ but reaches $58 \mathrm{mmol} / \mathrm{L} / \mathrm{m}$ at MD04-2740, located $150-200 \mathrm{~m}$ north of the chimneys, implying downward advection at MD04-2737 and upward advection or lateral flow at MD04-2740. The high salinity gradient in core MD04-2740 is obtained in the hemipelagic muds overlying the coarse sand layers and the sounder profiles show that sand layers dip toward the basin (from $12 \mathrm{~m}$ at MD 04-2740 to about $40 \mathrm{~m}$ depth in core at MD 04-2737; see Fig. 11). Buoyancy forces acting on the brackish fluid (lower density than seawater) will favor up-dip migration. This suggests that the sand layers channel fluids buried below the basin towards the fault, where they are expelled. The lower chlorinity gradient at MD04-2737 may result from seawater convective down-flow, or to entrainment of pore fluids with the sedimentation. If pore fluid from clay layer compaction in the basin is channelled toward the 
fault zone by sandy aquifers and expelled, a net down-flow of seawater is obtained in the basin. In a steady-state 1-D compaction model, this flux would be nearly zero (Hutchinson, 1985).

\section{Synthesis and discussion}

The distribution of cold seep sites in the Sea of Marmara results from a combination of factors. The tectonic control appears as the most important factor for the occurrence of fluid seepage. All seepage sites observed are found aligned on faults, channelling the fluid flow and gas discharge. One important question is to what extent this systematic association is influenced by observational bias. The ROV survey was designed to investigate fault scarps and most observations are restricted to a narrow (less than $400 \mathrm{~m}$ wide) band along suspected fault traces. However, it is possible to confirm a close association with faults because the vents are not located randomly along the observation tracks. The scale of observation of the fault-seep relationship may be determined in areas with bathymetric coverage where the ROV followed a sawtooth route (Fig. 14). As in this example, seeps were generally found within $50 \mathrm{~m}$ of the point where the ROV crossed the seafloor expression of the fault. Moreover, in the Tekirdağ Basin, most active seeping sites are aligned along fault scarps and are associated with the interplay of major faulting and secondary Riedel faults (Fig. 4). However, we cannot exclude the possibility that cold seeps completely unrelated to fault zones may exist in unexplored areas in the Sea of Marmara.

An interesting feature is the distinction that could be made between relatively common black patches and bacterial mats and very peculiar sites with active chimneys. So far, active chimneys have been observed at only two sites, in the Tekirdağ Basin, and on the northern edge of the Central Basin. The chimneys expel water, presumably brackish water trapped in 
the sediment during lacustrine times. The two sites where they are found have very similar settings: they are located on an active fault outcrop, at the outlet of a canyon and on the edge of a basin. We propose a logical explanation for this combination. At least in Tekirdağ, the canyon has fed coarse sand layers, which in turn provided pathways to drain fluids laterally from an area of at least $1 \mathrm{~km}^{2}$ in the basin toward the fault zone where they ascend to the seafloor. Furthermore, continued canyon activity can prevent the sealing of the fault conduits at the seafloor by removing hemipelagic draping. The outflow can result from three different processes that may be combined: compaction of the sediment in the basins, buoyancy driven convection and gas charging of the sand layers. These three processes may in theory be distinguished by flux and pore pressure measurements, which are not available at this stage. Overall, there is an apparent decrease of activity from west to east. While the Tekirdağ Basin has both more spectacular and more widespread activity than the Central Basin, the Western High also has more activity than the Central High. Finally, evidence for fluid expulsion is sparse in Çınarcık, and absent near the connection with the fault branches in Izmit Gulf which slipped in 1999. Possible explanations fall in three broad categories: (1) observation bias if ROV VICTOR missed important sites in Çınarcık Basin; (2) influence of the seismic cycle and recent earthquakes; (3) systematic changes in methane production and migration fluxes. We cannot discriminate these possibilities based on available evidence, but can formulate hypotheses. We remarked that the current pattern of fluid expulsion at the Tekirdağ chimney site reflects competition between permeability increase caused by fracturing in the fault zone and permeability decrease caused by authigenic carbonate precipitation. Earthquake rupture is expected to increase permeability of the slipped segments, or around the rupture tips (Curewitz and Karson, 1997). The permeability of the fault zone would then relate to the time elapsed since the last earthquake. The stronger activity in the west would thus be consistent with an offshore extension of the 1912 Ganos rupture, as suggested by Armijo et al. (2005). 
However, this hypothesis does not explain the activity on the NE edge of the Central Basin and does not fit the absence of activity in the easternmost Çınarcık Basin.

Alternatively, a higher methane flux in the western part of the Sea of Marmara could account for the more abundant cold seeps there. Data on gas origin in the Sea of Marmara are scarce and suggest primarily a biogenic origin, with a minor (1\% ethane + propane) thermogenic component (Halbach et al., 2002). However, the Tertiary Thrace Basin has potential for thermogenic methane generation and extends under the western part of the Sea of Marmara (Gurgey et al. 2005; Görür and Okay, 1996; Hoşgormez and Yalcin, 2005) (Fig. 1). The potential contribution of Thrace basin thermogenic gasses to cold seep activity in the western Sea of Marmara may be evaluated in the future by systematic characterization of gas chemical and isotopic composition at cold seeps.

\section{Conclusion}

Seafloor manifestations of fluid outflow in the Sea of Marmara have been investigated through ROV visual observations. All observed zones of seepage occur along the main active fault, acting as active conduits near the subsurface, especially when permeability is highest, i.e. at the interplay of major and secondary faulting. Two types of fluid migration should be distinguished: (1) methane free gas migration in the sediment has been inferred from echosounder acoustic anomaly and bubble emissions triggered by coring and occur at black patches of reduced sediments; (2) highly-focused brackish pore water expulsion through authigenic carbonate chimneys occurs in the Tekirdağ and Central basins at the intersection of outlets of canyons and active fault scarps. A mechanism accounting for this observation is that fluids may be channelled along high permeability sand strata towards the active fault 
scarp, and are expelled where erosion is the most active. This hypothesis is supported by pore fluid chemistry profiles, at least for the venting sites located within the Tekirdağ Basin.

\section{Acknowledgements}

The MARMARASCARPS and MARMARA-VT cruises were performed within the framework of the collaborative program on the seismic risk in the Istanbul and Sea of Marmara region coordinated by the Turkish TUBITAK and the French INSU-CNRS, with support from the French Ministry of Foreign Affairs (MAE). Naci Görür from TUBITAK is thanked for coordinating the effort in Turkey. Rolando Armijo, who coordinates this program in France, is thanked for providing us the ROV videos and the microbathymetric data of the MARMARASCARPS cruise. Nicolas Pondard is thanked for his help digitizing the videos. We thank Claude Rangin for providing us his personal on-board observations during MARMARASCARPS cruise. We thank Xavier Le Pichon for his comments on an earlier version of the manuscript and three anonymous referees for their constructive review. We are grateful to the captain of $\mathrm{R} / \mathrm{V}$ MARION DUFRESNE, and the whole crew for their involvement during the MD138 expedition (MARMARA-VT, MARMACORE2, ASSEMBLAGE). The post-cruise investigations have been funded by the various involved CNRS laboratories. We acknowledge financial support from the INSU MARMAFLUIDES and ANR ISIS projects. 


\section{Bibliography}

Aksu, A., Hiscott, R., Yasar, D., 1999. Oscillating Quaternary Water Levels of the Marmara Sea and Vigorous Outflow into the Aegean Sea from the Marmara Sea Black Sea Drainage Corridor. Marine Geology 153, 275-302.

Aloisi, G., Pierre, C., Rouchy, J.-M., Foucher, J.-P., Woodside, J., 2000. Methane-Related Authigenic Carbonates of Eastern Mediterranean Sea Mud Volcanoes and Their Possible Relation to Gas Hydrate Destabilisation. Earth and Planetary Science Letters 184 (1), 321-338.

Alpar, B., 1999. Underwater Signatures of the Kocaeli Earthquake of 17 August 1999 in Turkey. Turkish Journal of Marine Sciences 5, 111-130.

Armijo, R., Meyer, B., Navarro, S., King, G., 2002. Asymetric Slip Partitioning in the Sea of Marmara Pull-Apart: A Clue to Propagation Processes of the North Anatolian Fault? Terra Nova 13, 80-86.

Armijo, R., Pondard, N., Meyer, B., Ucarkus, G., Mercier de Lepinay, B., Malavieille, J., Dominguez, S., Gustcher, M.A., Schmidt, S., Beck, C., Çagatay, N., Cakir, Z., Imren, C., Eris, K., Natalin, B., Ozalaybey, S., Tolun, L., Lefevre, I., Seeber, L., Gasperini, L., Rangin, C., Emre, O., Sarikavak, K., 2005. Submarine Fault Scarps in the Sea of Marmara Pull-Apart (North Anatolian Fault): Implications for Seismic Hazard in Istanbul. Geochemistry, Geophysics and Geosystems 6, Q06009, doi:10.1029/2004GC000896.

Beck, C., Mercier de Lepinay, B., Schneider, J.-L., Cremer, M., Çagatay , N., Wendenbaum, E., Boutareaud, S., Menot-Combes, G., Schmidt, S., Weber, O., Eris, K., Armijo, R., Meyer, B., Pondard, N., Gutcher, M.-A., Turon, J. L., Labeyrie, L., Cortijo, E., Gallet, Y., Bouquerel, H., Görür, N., Gervais, A., Castera, M. H., Londeix, L., de Resseguier, 
A. and Jaouen, A., 2007. Late Quaternary Co-Seismic Sedimentation in the Sea of Marmara's Deep Basins. Sedimentary Geology, 199 (1-2), 65-89, doi: 10.1016/j.sedgeo.2005.12.031.

Bouriak, S., Vanneste, M., Saoutkine, A., 2000. Inferred gas hydrates and clay diapirs near the Storegga Slide on the southern edge of the Voring Plateau, offshore Norway. Marine Geology 163 (1-4), 125-148.

Brown, K.M., Saffer, D.M., Bekins, B.A., 2001. Smectite Diagenesis, Pore-Water Freshening, and Fluid Flow at the Toe of the Nankai Wedge. Earth and Planetary Science Letters 194 (1-2), 97-109.

Çagatay, M.N., Gorur, N., Algan, O., Eastoe, C.S., Tchapalygya, A., Ongan, D., Kuhn, T., Kuscu, I., 2000. Late Glacial-Holocene Palaeoceanography of the Sea of Marmara: Timing of Connections with the Mediterranean and the Black Sea. Marine Geology 167, 191-206.

Çagatay, M.N., Gorur, N., Polonia, A., Demirbag, E., Sakinc, M., Cormier, M. H., Capotondi, L., McHugh, C., Emre, O., Eris, K., 2003. Sea-Level Changes and Depositional Environments in the Izmit Gulf, Eastern Marmara Sea, During the Late GlacialHolocene Period. Marine Geology 202 (3-4), 159-173.

Çagatay, M. N., Ozcan, M., Gungor, E., 2004. Pore-water and sediment geochemistry in the Marmara Sea (Turkey); early diagenesis and diffusive fluxes. Geochemistry: Exploration, Environment, Analysis 4 (3), 213-225.

Chamot-Rooke, N., Rabaute, A., Kreemer, C., 2005. Western Mediterranean Ridge Mud Belt Correlates with Active Shear Strain at the Prism-Backstop Geological Contact. Geology 33 (11), 861-864.

Charlou, J.L., Donval, J.P., Zitter, T., Roy, N., Jean-Baptiste, P., Foucher, J.P., Woodside, J., 2003. Evidence of Methane Venting and Geochemistry of Brines on Mud Volcanoes of 
the Eastern Mediterranean Sea. Deep-Sea Research Part I-Oceanographic Research Papers 50 (8), 941-958.

Crank, J., 1975. The Mathematics of Diffusion. Oxford University Press, London, 414 pp.

Curewitz, D., Karson, J. A., 1997. Structural Settings of Hydrothermal Outflow: Fracture Permeability Maintained by Fault Propagation and Interaction. Journal of Volcanology and Geothermal Research 79 (3-4), 149-168.

De Lange, G., Brumsack, H. J., 1998. The Occurence of Gas Hydrates in Eastern Mediterranean Mud Dome Structures as Indicated by Pore-Water Composition. In: Henriet, J., Mienert, J. (Eds.), Gas Hydrates: Relevance to World Margin Stability and Climate Change. Geological Society of London, London, 167-175.

Demirbag, E., Rangin, C., Le Pichon, X. and Şengor, C.A.M., 2003. Investigation of the Tectonics of the Main Marmara Fault by Means of Deep-Towed Seismic Data. Tectonophysics 361, 1-19.

Dimitrov, L., Woodside, J., 2003. Deep Sea Pockmark Environments in the Eastern Mediterranean. Marine Geology 195 (1-4), 263-276.

Dimitrov, L.I., 2003. Mud Volcanoes - a Significant Source of Atmospheric Methane. GeoMarine Letters 23 (3-4), 155-161.

Gürgey, K., Philp, R.P., Clayton, C., Emiroğlu H., Siyako M., 2005. Geochemical and isotopic approach to maturity/source/mixing estimations for natural gas and associated condensates in the Thrace Basin, NW Turkey. Applied Geochemistry 20 (11), 20172037.

Görür, N., Okay N., 1996. A fore-arc origin for the Thrace Basin, NW Turkey. Geologische Rundschau 85 (4), 662-668.

Halbach, P., Kusçu, I., Inthorn, M., Kuhn, T., Pekdeger, A., Seifert, R., 2002. Methane in sediments of the deep Marmara Sea and its relation to local tectonic structures. In: 
Görür, N., Papadopulos, G.A., Okay, N. (Eds.) Integration of Science Research on the 1999 Turkish and Greek Earthquakes, NATO Science Series IV earth and environmental sciences 9, 71-85.

Halbach, P., Holzbecher, E., Reichel, T., Moche, R., 2004. Tectonically Induced Fluid Migration of the Sulphate-Methane-Reaction Zone in Marine Sediments of the Sea of Marmara - a Case Study. Chemical Geology 205 (1-2), 73-82.

Henry, P., Le Pichon, X., Lallemant, S., Lance, S., Martin, J. B., Foucher, J. P., Fiala Medioni, A., Rostek, F., Guilhaumou, N., Pranal, V., Castrec, M., 1996. Fluid Flow in and around a Mud Volcano Field Seaward of the Barbados Accretionary Wedge: Results from Manon Cruise. Journal of Geophysical Research-Solid Earth 101 (B9), 20297-20323.

Henry, P., Thomas, M., Ben Clennell, M., 1999. Formation of natural gas hydrates in marine sediments- 2. Thermodynamic calculations of stability conditions in porous sediments. Journal of Geophysical Research-Solid Earth 104 (B10), 23005-23022.

Henry, P., Lallemant, S., Nakamura, K., Tsunogai, U., Mazzotti, S., Kobayashi, K., 2002. Surface Expression of Fluid Venting at the Toe of the Nankai Wedge and Implications for Flow Paths. Marine Geology 187 (1-2), 119-143.

Hoşgormez, H., Yalcin, M.N., 2005. Gas-Source Rock Correlation in Thrace Basin, Turkey. Marine and Petroleum Geology 22, 901-916.

Hovland, M., Talbot, M.R., Qvale, H., Olaussen, S., Aasberg, L., 1987. Methane-Related Carbonate Cements in Pockmarks of the North-Sea. Journal of Sedimentary Petrology 57 (5), 881-892.

Hovland, M., Judd, A., 1988. Seabed pockmarks and seepages. Impact on geology, biology and the marine environment. Graham and Trotman, London, 293 pp. 
Hovland, M., 2002. On the Self-Sealing Nature of Marine Seeps. Continental Shelf Research 22, 16, 2387-2394.

Hovland, M., 2003. Geomorphological, Geophysical, and Geochemical Evidence of Fluid Flow through the Seabed. Journal of Geochemical Exploration 78-79, 287-291.

Hutchison, I., 1985. The effects of sedimentation and compaction on oceanic heat flow.

Geophysical journal of the Royal Astronomical Society 82, 439-459.

Imren, C., Le Pichon, X., Rangin, C., Demirbag, E., Ecevitoglu, B., Görür, N., 2001. The North Anatolian Fault within the Sea of Marmara: A New Interpretation Based on Multi-Channel Seismic and Multi-Beam Bathymetry Data. Earth and Planetary Science Letters 186, 143-158.

Judd, A.G., Hovland, M., 2007. Seabed Fluid Flow. Impact on geology, biology, and the marine environment. Cambridge University Press, Cambridge, 470 pp.

Juniper, S.K., Sibuet, M., 1987. Cold Seep Benthic Communities in Japan Subduction Zones Spatial-Organization, Trophic Strategies and Evidence for Temporal Evolution. Marine Ecology-Progress Series 40 (1-2), 115-126.

Kopf, A., Deyhle, A., 2002. Back to the Roots: Boron Geochemistry of Mud Volcanoes and Its Implications for Mobilization Depth and Global B Cycling. Chemical Geology 192 (3-4) 195-210.

Kulm, L.D., Suess, E., Moore, J.C., Carson, B., Lewis, B.T., Ritger, S.D., Kadko, D.C., Thornburg, T.M., Embley, R.W., Rugh, W.D., Massoth, G.J., Langseth, M.G., Cochrane, G.R., Scamman, R.L., 1986. Oregon Subduction Zone - Venting, Fauna, and Carbonates. Science 231 (4738), 561-566.

Kulm, L.D., Suess, E., 1990. Relationship between Carbonate Deposits and Fluid Venting Oregon Accretionary Prism. Journal of Geophysical Research-Solid Earth and Planets 95 (B6), 8899-8915. 
Kuscu, I., Okamura, M., Matsuoka, H., Gokasan, E., Awata, Y., Tur, H., Simsek, M., 2005. Seafloor Gas Seeps and Sediment Failures Triggered by the August 17, 1999 Earthquake in the Eastern Part of the Gulf of Izmit, Sea of Marmara, NW Turkey. Marine Geology 215, 193-214.

Le Pichon, X., Kobayashi, K., Cadet, J. P., Ashi, J., Boulegue, J., Chamot-rooke, N., Fiala Medioni, A., Foucher, J. P., Furuta, T., Gamo, T., Henry, P., Iiyama, J. T., Lallemand, S. E., Lallemant, S. J., Ogawa, Y., Sakai, H., Segawa, J., Sibuet, M., Taira, A., Takeuchi, A., Tarits, P. and Toh, H., 1992. Fluid Venting Activity within the Eastern Nankai Trough Accretionary Wedge - a Summary of the 1989 Kaiko-Nankai Results. Earth and Planetary Science Letters 109 (3-4), 303-318.

Le Pichon, X., Sengor, A. M. C., Demirbag, E., Rangin, C., Imren, C., Armijo, R., Görür, N., Çagatay, N., Mercier de Lépinay, B., Meyer, B., Saatcilar, R. and Tok, B., 2001. The Active Main Marmara Fault. Earth and Planetary Science Letters 192, 595-616.

Le Pichon, X., Chamot-Rooke, N., Rangin, C., Sengor, A. M. C., 2003. The North Anatolian Fault in the Sea of Marmara. Journal of Geophysical Research 108 (B4), 2179, doi:101029/2002JB001862.

Li, Y.-H. and Gregory, S., 1974. Diffusion of Ions in Sea Water and in Deep-Sea Sediments. Geochimica et Cosmochimica Acta 38 (5), 703-714.

Martin, J.B., Kastner, M., Henry, P., Le Pichon, X., Lallemant, S., 1996. Chemical and Isotopic Evidence for Sources of Fluids in a Mud Volcano Field Seaward of the Barbados Accretionary Wedge. Journal of Geophysical Research-Solid Earth 101 (B9), 20325-20345.

McClusky, S., Balassanian, S., Barka, A., Demir, C., Ergintav, S., Georgiev, I., Gurkan, O., Hamburger, M., Hurst, K., Kahle, H., Kastens, K., Kekelidze, G., King, R., Kotzev, V., Lenk, O., Mahmoud, S., Mishin, A., Nadariya, M., Ouzounis, A., Paradissis, D., Peter, 
Y., Prilepin, M., Reilinger, R., Sanli, I., Seeger, H., Tealeb, A., Toksoz, M.N., Veis, G., 2000. Global Positioning System Constraints on Plate Kinematics and Dynamics in the Eastern Mediterranean and Caucasus. Journal of Geophysical Research 105, 5695-5719. Meade, B.J., Hager, B.H., McClusky, S.C., Reilinger, R.E., Ergintav, S., Lenk, O., Barka, A., Ozener, H., 2002. Estimates of seismic potential in the Marmara Sea region from block models of secular deformation constrained by global positioning system measurements. Bulletin of the Seismological Society of America 92 (1), 208-215.

Michaelis, W., Seifert, R., Nauhaus, K., Treude, T., Thiel, V., Blumenberg, M., Knittel, K., Gieseke, A., Peterknecht, K., Pape, T., Boetius, A., Amann, R., Jorgensen, B.B., Widdel, F., Peckmann, J. R., Pimenov, N.V. and Gulin, M.B., 2002. Microbial Reefs in the Black Sea Fueled by Anaerobic Oxidation of Methane. Science 297 (5583) 10131015.

Moore, J.C., Orange, D. and Kulm, L.D., 1990. Interrelationship of Fluid Venting and Structural Evolution - Alvin Observations from the Frontal Accretionary Prism, Oregon. Journal of Geophysical Research-Solid Earth and Planets 95 (B6), 8795-8808.

Olu-Le Roy, K., Sibuet, M., Fiala Medioni, A., Gofas, S., Salas, C., Mariotti, A., Foucher, J. P., Woodside, J., 2004. Cold Seep Communities in the Deep Eastern Mediterranean Sea: Composition, Symbiosis and Spatial Distribution on Mud Volcanoes. Deep-Sea Research Part I-Oceanographic Research Papers 51 (12), 1915-1936.

Olu, K., Duperret, A., Sibuet, M., Foucher, J. P., Fiala Medioni, A., 1996. Structure and Distribution of Cold Seep Communities Along the Peruvian Active Margin: Relationship to Geological and Fluid Patterns. Marine Ecology-Progress Series 132 (13), 109-125.

Orange, D.L., Greene, H.G., Reed, D., Martin, J.B., McHugh, C. M., Ryan, W.B.F., Maher, N., Stakes, D., Barry, J., 1999. Widespread Fluid Expulsion on a Translational 
Continental Margin: Mud Volcanoes, Fault Zones, Headless Canyons, and OrganicRich Substrate in Monterey Bay, California. Geological Society of America Bulletin 111 (7), 992-1009.

Papatheodorou, G., Hasiotis, T., Ferentinos, G., 1993. Gas-Charged Sediments In The Aegean And Ionian Seas, Greece. Marine Geology 112 (1-4), 171-184.

Pätzold, J., Halbach, P.E., Hempel, G., Weikert, H., 2000. Östliches Mittelmeer-Nördliches Rotes Meer 1999, Cruise $N^{\circ}$ 44, 22 January-16 May 1999. Meteor Berichte 00-3, Universität Hamburg, 240 pp.

Paull, C.K., Hecker, B., Commeau, R., Freemanlynde, R.P., Neumann, C., Corso, W.P., Golubic, S., Hook, J.E., Sikes, E., Curray, J., 1984. Biological Communities at the Florida Escarpment Resemble Hydrothermal Vent Taxa. Science 226 (4677), 965-967.

Rangin, C., Demirbag, E., Imren, C., Crusson, A., Normand, A., Le Drezen, E., Le Bot, A., 2001. Marine Atlas of the Sea of Marmara (Turkey). Ifremer, Brest.

Rangin, C., Le Pichon, X., Demirbag, E., Imren, C., 2004. Strain Localization in the Sea of Marmara: Propagation of the North Anatolian Fault in a Now Inactive Pull-Apart. Tectonics 23, TC2014, doi:10.1029/2002TC001437.

Ryan, W.B.F., Major, C.O., Lericolais, G. and Goldstein, S.L., 2003. Catastrophic Flooding of the Black Sea. Annual Reviews: Earth and Planetary Sciences 31, 525-554.

Sassen, R., Roberts, H.H., Aharon, P., Larkin, J., Chinn, E.W., Carney, R., 1993. Chemosynthetic Bacterial Mats at Cold Hydrocarbon Seeps, Gulf of Mexico Continental-Slope. Organic Geochemistry 20 (1), 77-89.

Sibuet, M., Juniper, S.K., Pautot, G., 1988. Cold-Seep Benthic Communities in the Japan Subduction Zones - Geological Control of Community-Development. Journal of Marine Research 46 (2), 333-348. 
Sibuet, M., Olu, K., 1998. Biogeography, Biodiversity and Fluid Dependence of Deep-Sea Cold-Seep Communities at Active and Passive Margins. Deep-Sea Research Part IiTopical Studies in Oceanography 45 (1-3), 517-567.

Teichert, B.M.A., Bohrmann, G., Suess, E., 2005. Chemoherms on Hydrate Ridge - Unique Microbially-Mediated Carbonate Build-Ups Growing into the Water Column. Palaeogeography, Palaeoclimatology, Palaeoecology 227 (1-3), 67-85.

Tsunogai, U., Yoshida, N., Gamo, T., 2002. Carbon Isotopic Evidence of Methane Oxidation through Sulfate Reduction in Sediment beneath Cold Seep Vents on the Seafloor at Nankai Trough. Marine Geology 187 (1-2), 145-160.

Von Rad, U., Rosch, H., Berner, U., Geyh, M., Marchig, V., Schulz, H., 1996. Authigenic Carbonates Derived from Oxidized Methane Vented from the Makran Accretionary Prism Off Pakistan. Marine Geology 136 (1-2), 55-77.

Wallmann, K., Linke, P., Suess, E., Bohrmann, G., Sahlng, H., Schluter, M., Dahlmann, A., Lammers, S., Greinert, J., von Mirbach, N., 1997. Quantifying Fluid Flow, Solute Mixing, and Biogeochemical Turnover at Cold Vents of the Eastern Aleutian Subducton Zone. Geochimica et Cosmochimica Acta 61, 5209-5219.

Wessel, P., Smith, W.H.F., 1991. Free Software Helps Map and Display Data. EOS Transactions, American Geophysical Union 72, 441-441.

You, C.-F., Spivack, A.J., Smith, J.H., Gieskes, J.M., 1993. Mobilization of boron at convergent margins: Implications for boron geochemical cycle. Geology 21, 207-210.

Zitter, T.A.C., Woodside, J.M., Mascle, J., 2003. The Anaximander Mountains: A Clue to the Tectonics of Southwest Anatolia. Geological Journal 38 (3-4), 375-394.

Zitter, T.A.C., Huguen, C., Woodside, J. M., 2005. Geology of Mud Volcanoes in the Eastern Mediterranean from Combined Sidescan Sonar and Submersible Surveys. Deep-Sea Research Part I-Oceanographic Research Papers 52 (3), 457-475. 
Zitter, T. A.C., Huguen, C., ten Veen, J., Woodside, J.M., 2006. Tectonic Control on Mud Volcanism in the Anaximander Mountains. In: Dilek, Y., Pavlides, S. (Eds), Post Collisional Tectonics and Magmatism in the Eastern Mediterranean Region. Geological Society of America, special paper, 615-631. 


\section{Figures}

Figure 1: Map of the Sea of Marmara region and the North Anatolian fault zone (NAFZ); Mercator projection. Background is GTopo30 Global topography data; contours are every 100 m. Abbreviations are as follow: TB: Tekirdağ Basin. CB: Central Basin. ÇB: Çınarcık Basin. The inset shows its location within the eastern Mediterranean geodynamic framework (modified after McClusky et al., 2000; Zitter et al., 2003). Dashes are the limit of the Thrace Basin from Hoşgormez and Yalcin (2005).

Figure 2: Shaded multibeam bathymetric map of the Sea of Marmara from Suroit EM300 data with the fault trace expression on seafloor (From Le Pichon et al., 2001) and the location of MARMARA-VT cores (Mercator projection). Abbreviations are as follow: TB: Tekirdağ Basin. CB: Central Basin. ÇB: Çınarcık Basin, KB: Kumburgaz Basin, WH: Western High, CH: Central High.

Figure 3: Map of the venting sites in the Tekirdağ Basin and on the Western High; projection Mercator. Background is shaded EM300 multibeam. The location of the dive tracks with visual observations, the location of the sounder profiles (Fig. 9) and the location of MARMARAVT cores are shown.

Figure 4: Detailed map of the carbonate chimneys location shown by stars (T1 to T7, see text for description) in the Tekirdağ Basin, and ROV seafloor photographs of the carbonate chimneys. Background is ROV microbathymetric data. The outcrop of carbonate crusts and the location of the dive tracks are also shown.

Figure 5: Seafloor photo mosaic and drawing of a $1 \mathrm{~m}$ high recent seismic rupture and exposition of a carbonate chimney plumbing system.

Figure 6: Map of the Central Basin venting sites. Background is shaded EM300 multibeam. Location of the sounder profiles and MARMARAVT cores is shown. Legend is in Fig. 3. 
Figure 7: (a) Detailed map of ROV dive 11 (MARMARASCARPS cruise) and seepage sites in the Central Basin with seafloor photographs of (a) isolated dark patches on seafloor, (b) carbonate crust $1 \mathrm{~m}$ thick slab, (c) and (d) carbonate chimneys C1 and C2, and (e) 3 m high anthill-like carbonate pile. Legend is in Fig. 3.

Figure 8: Map of the Çınarcık Basin venting sites with location of the sounder profiles and the MARMARAVT cores; projection Mercator. Background is shaded EM300 multibeam.

Figure 9: (a) MARMARAV T chirp profile (frequency of $3.5 \mathrm{kHz}$ ) in the Central Basin with evidence of acoustic masking due to gas in the sediments. (b) MARMARASCARPS chirp profile (frequency of $3.5 \mathrm{kHz}$ ) across the fault scarp with evidence of gas acoustic anomaly. The location of the lines is indicated in Fig. 6.

Figure 10: (a) NNW-SSE oriented chirp profile (frequency of $3.5 \mathrm{kHz}$ ) from MARMARASCARPS cruise (location in Fig. 3) showing acoustic turbidity (AT) along the northern slope of the Basin, and near the canyon outlet. (b) WNW-ESE chirp profile (frequency of $3.5 \mathrm{kHz}$ ) from MARMARASCARPS cruise (location in Fig. 3) across the outlet of the canyon in the SE Tekirdağ Basin. Note the acoustic turbid zone between shotpoints 820 and 420. Vertical lines indicate the cross point of each profile.

Figure 11: (a) Chirp profile (frequency of $3.5 \mathrm{kHz}$ ) from MARMARASCARPS cruise (close up from Fig.10a) in the Tekirdağ Basin and the corresponding line-drawing above. The profile shows strong reflective horizons (horizons a, b, c, d) corresponding to coarser sand layers, and noisy reflection caused by gas, represented in grey on the line-drawing. The position and length of cores MD042737 and MD042740 are indicated on the profile assuming a velocity of $1600 \mathrm{~m} / \mathrm{s}$ within the sediment. MD042740 is projected on the profile, as it was recovered 400 m eastward (Fig. 3). (b) Description logs of the MD042737 and MD042740, showing the presence of coarse sand and shelly layers in both cores. The correlation with the strong reflective horizons is indicated. Note that the MD042737 core length has been 
corrected from the total amount of voids due to gas expansion $(670 \mathrm{~cm})$ and therefore is shorter than total length given in Tab. 1.

Figure 12: Depth profiles of chloride concentrations within pore fluids for cores MD04-2737. MD04-2740, MD04-2741, and MD04-2742 (see Fig. 2, 3 and 6 for location). Values are given in Tab. 2. The grey profiles are the diffusion pattern modeled as an error function for reference (see explanations in the text). Model 1 is an example of diffusion profile shown for instant salinization at 14000 years B.P. of a freshlake $\left[\mathrm{Cl}^{-1}\right]=0$ and model 2 for $\left[\mathrm{Cl}^{-1}\right]=100$ $\mathrm{mmol} / \mathrm{L}$.

Figure 13: Crossplots of $\mathrm{Cl}$ versus $\mathrm{Na}, \mathrm{Mg}, \mathrm{K}, \mathrm{B}$ and $\mathrm{SO}_{4}$. Values are given in Tab. 2. The solid lines indicate a mixing line between a seawater end-member and a low salinity endmember. Possible fluid composition for this low salinity end-member is indicated in bold on the mixing line (see text for explanation). Arrows indicate bottom seawater value in the Sea of Marmara.

Figure 14: Detailed area of dive 11 illustrating the relationship of the venting site location with the fault trace on seafloor. Legend is in Fig. 3. 


\section{Tables}

Table 1: MARMARA-VT cores length and location.

\begin{tabular}{|c|c|c|c|c|}
\hline Core & Latitude & Longitude & Waterdepth $(\mathrm{m})$ & Core length $(\mathrm{m})$ \\
\hline \hline MD04-2737 & $40^{\circ} 38.75^{\prime} \mathrm{N}$ & $27^{\circ} 37.21^{\prime} \mathrm{E}$ & 1117 & 41.85 \\
\hline MD04-2740 & $40^{\circ} 48.24^{\prime} \mathrm{N}$ & $27^{\circ} 43.54^{\prime} \mathrm{E}$ & 1110 & 24.47 \\
\hline MD04-2741 & $40^{\circ} 47.82^{\prime} \mathrm{N}$ & $27^{\circ} 37.69^{\prime} \mathrm{E}$ & 592 & 32 \\
\hline MD04-2742 & $40^{\circ} 48.73^{\prime} \mathrm{N}$ & $28^{\circ} 00.52^{\prime} \mathrm{E}$ & 1245 & 32.93 \\
\hline
\end{tabular}

Table 2: Pore water chemical composition of MARMARA-VT samples. Abbreviations are as follow: BSF: below seafloor, RSD: relative standard deviation. 


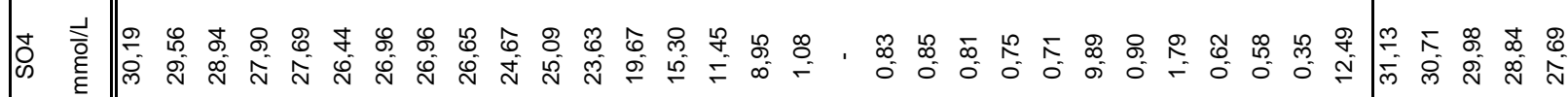
害 |

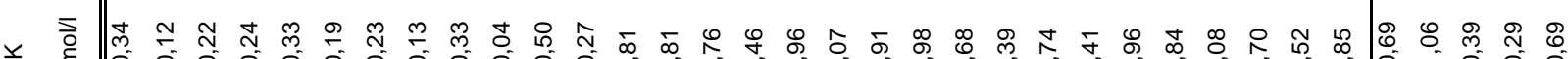

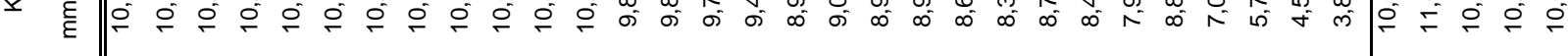
音 |

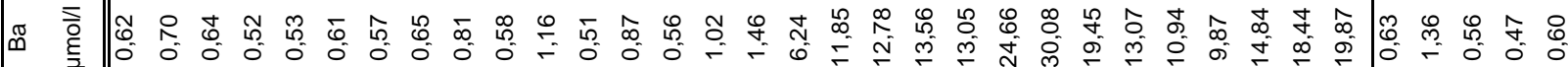
每 |

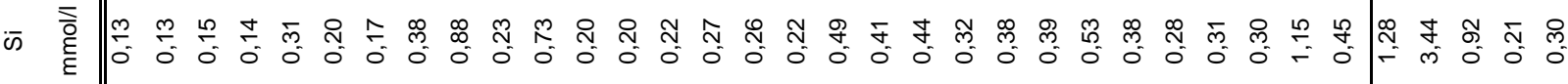

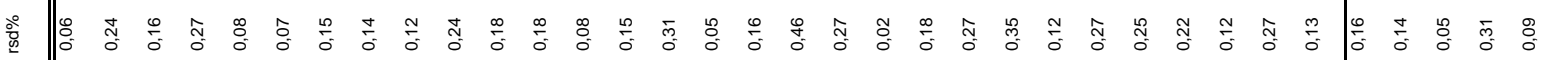

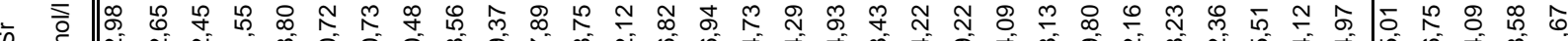
ஸे

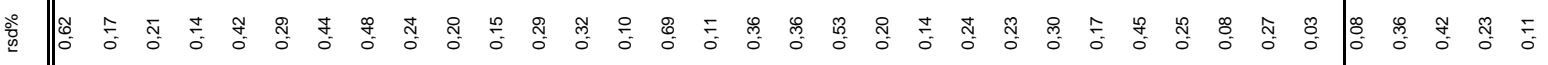
이

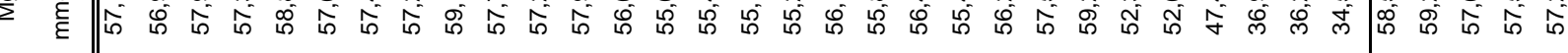

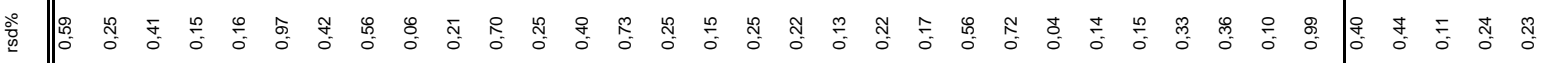

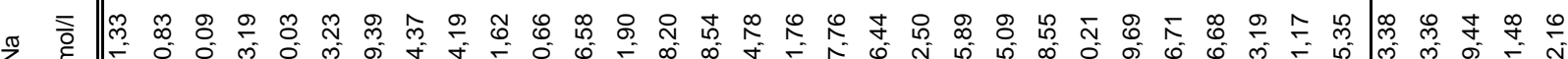

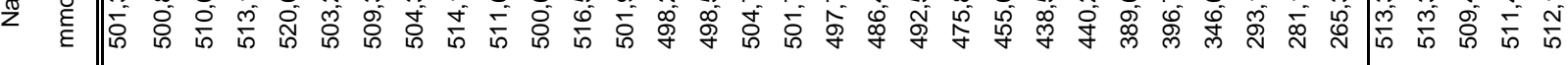

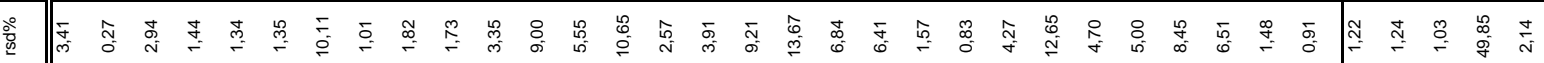

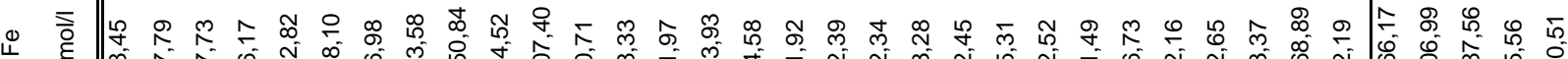
L

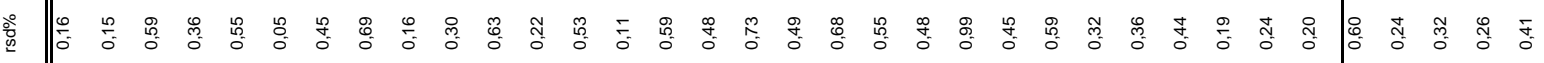

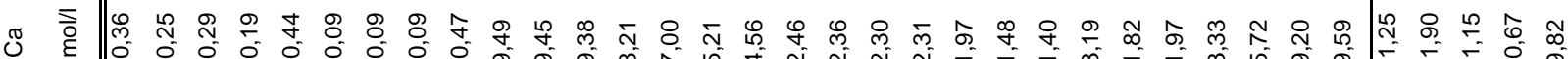

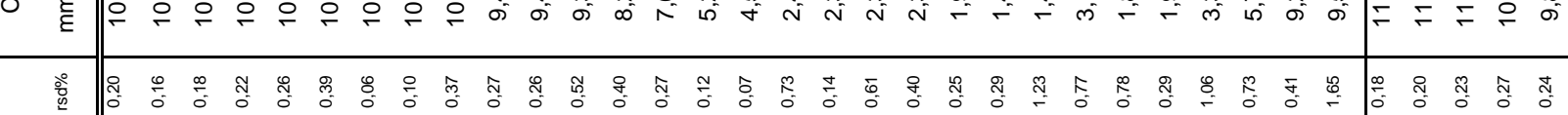
들

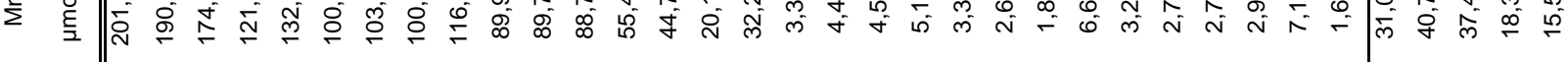

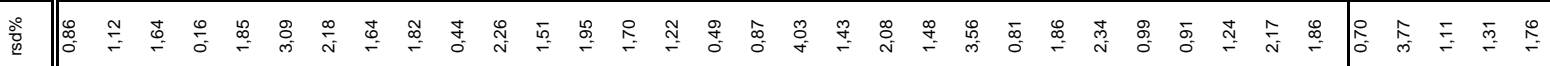

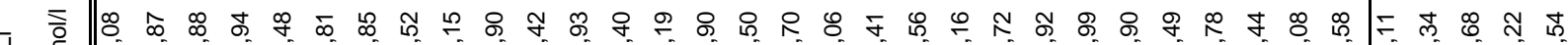
-

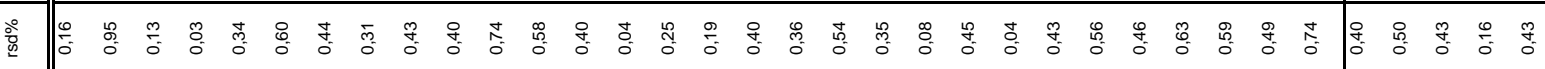

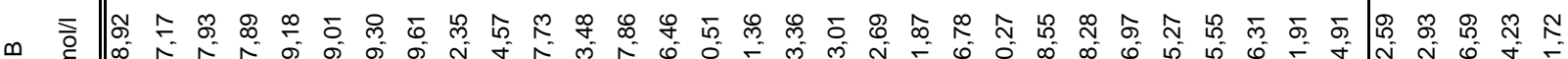

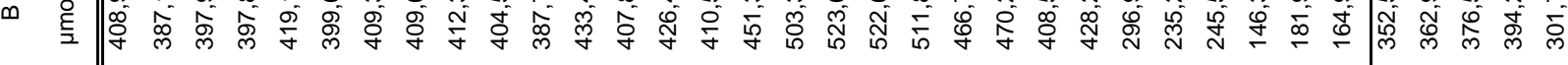
ত 言岩

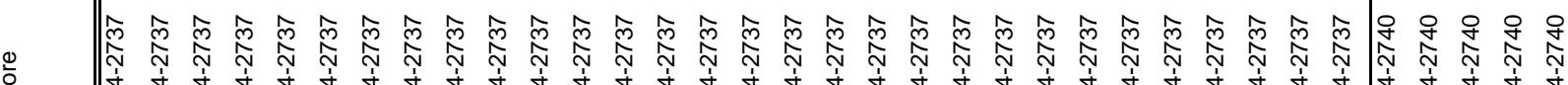

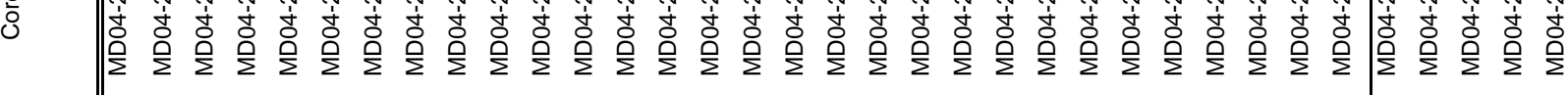




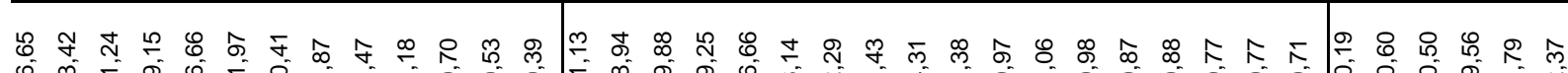
造

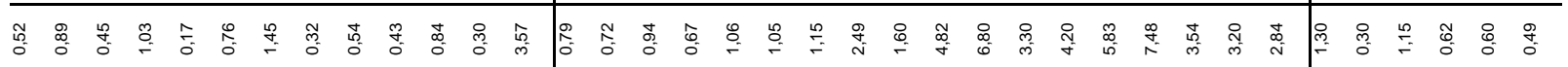

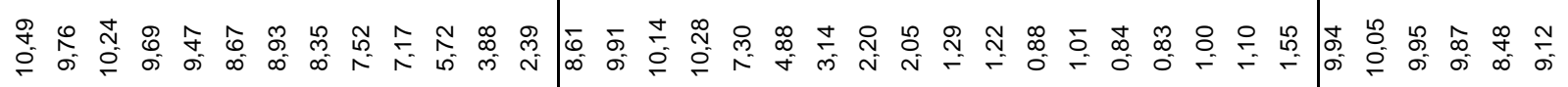

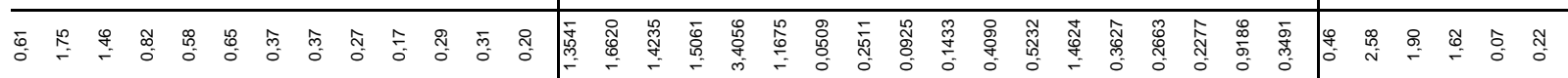

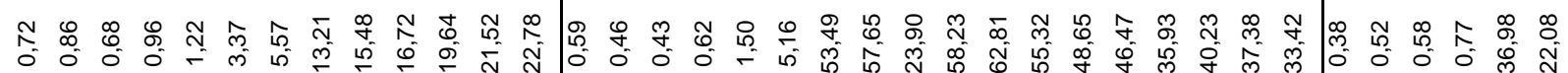

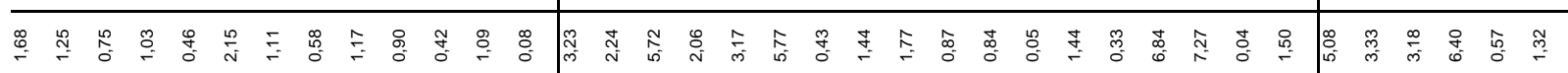

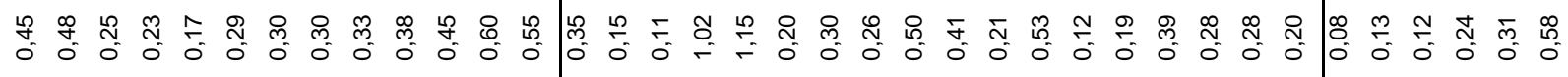

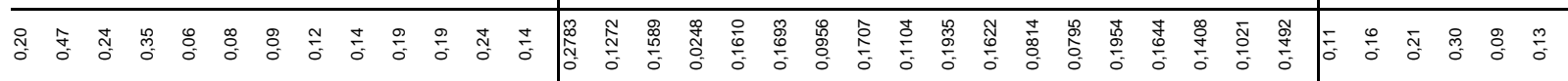

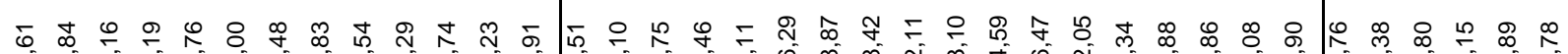

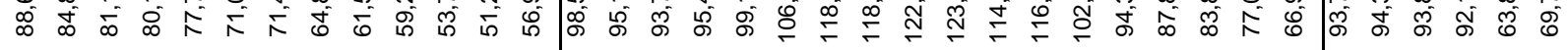

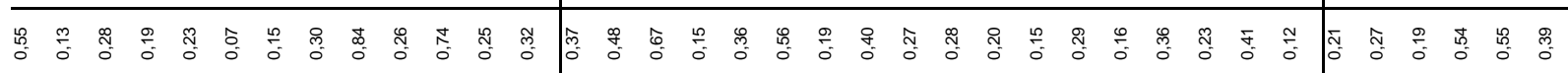

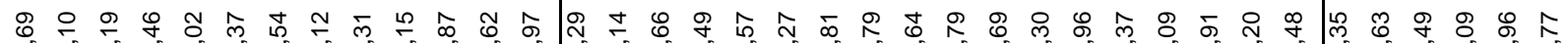

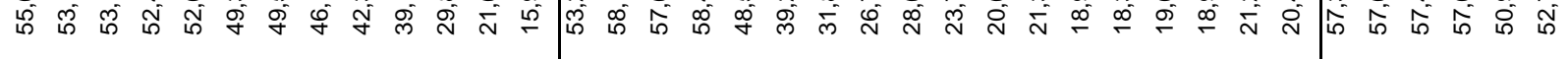

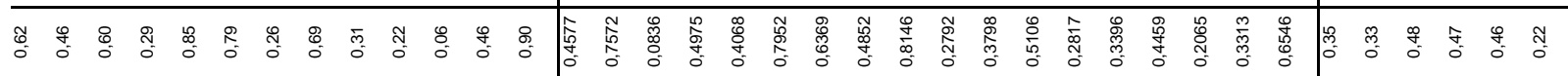

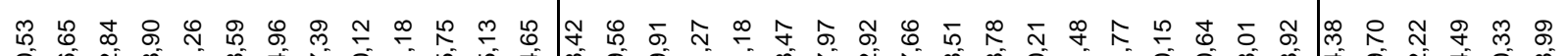

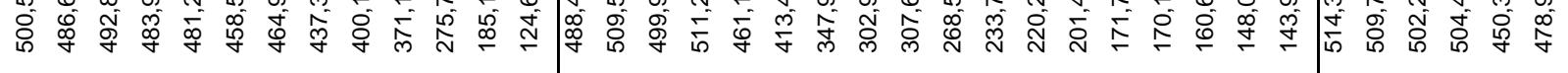

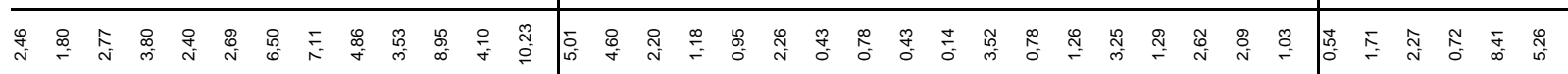

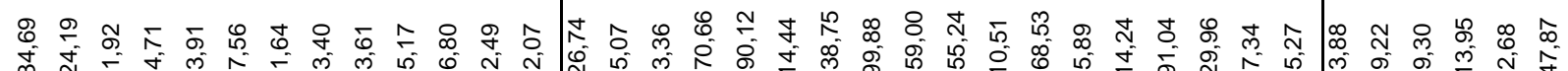

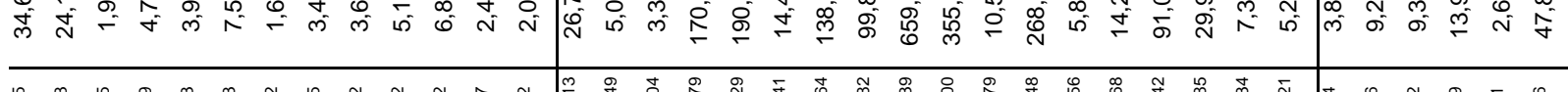

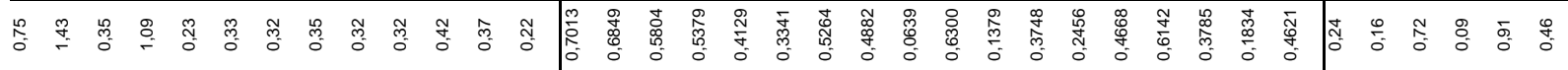

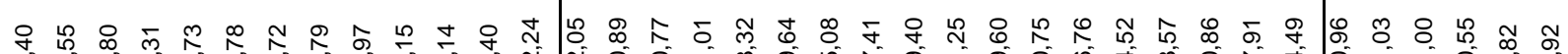
ब.

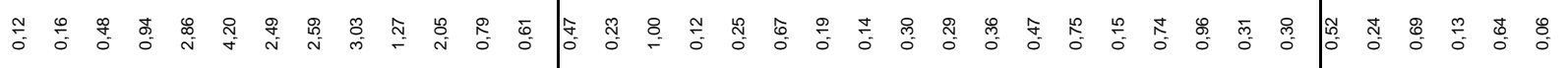

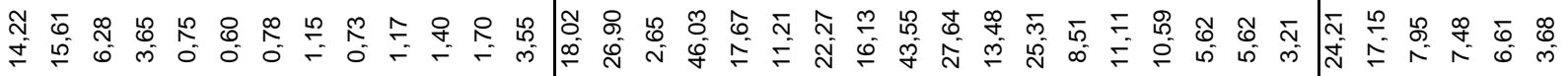

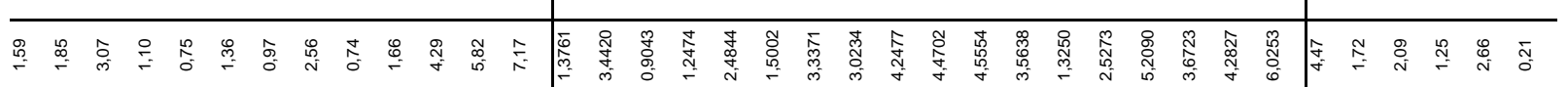

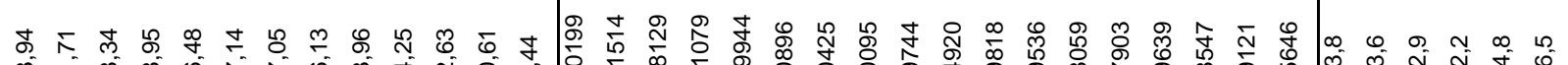
等

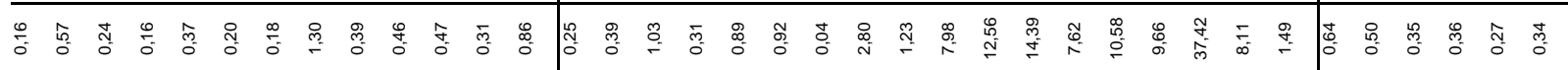
요염

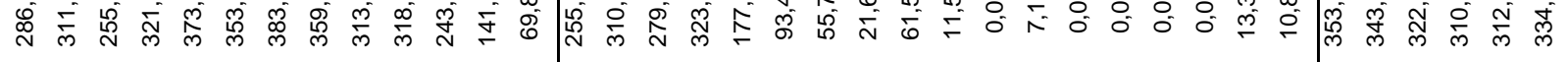

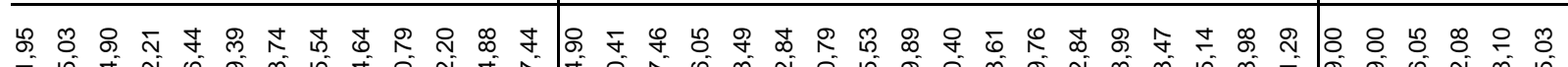

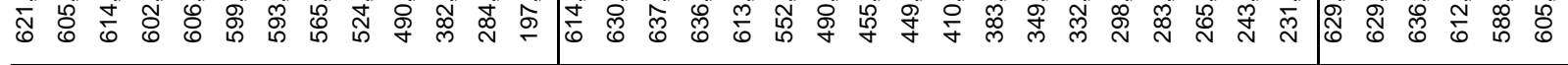

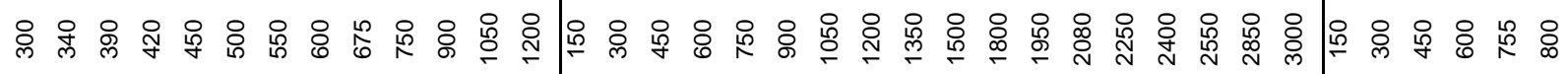

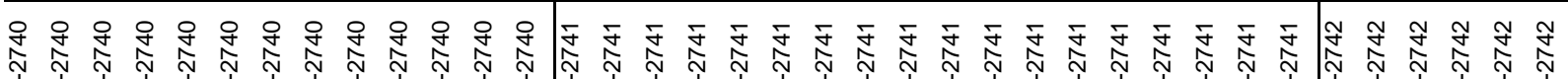

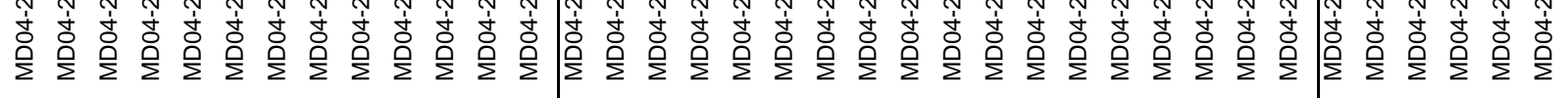




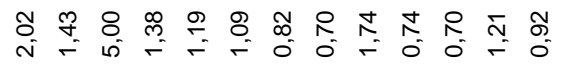

孚兽

可蛋

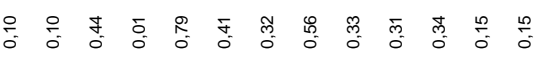

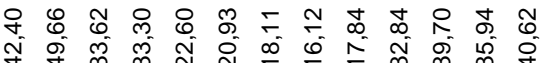
क्ष 采雚

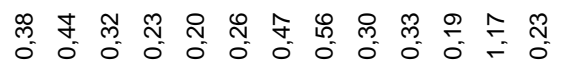

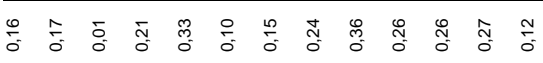
భ

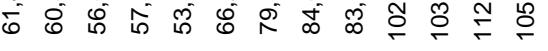

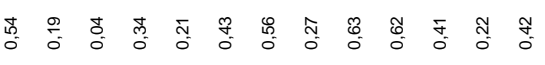

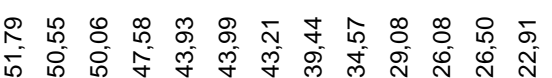

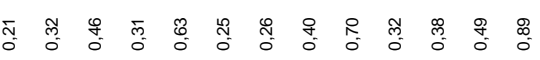

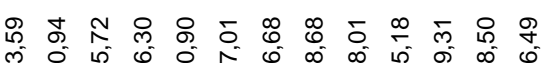

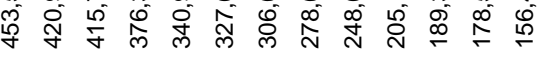

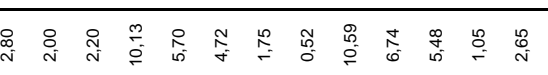

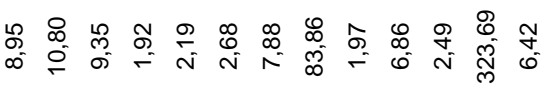

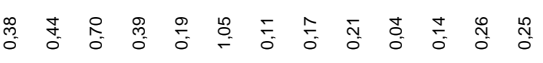

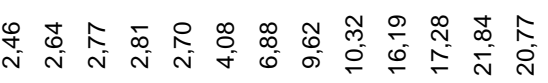
青䄓 等 苾

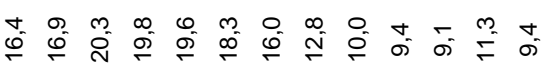

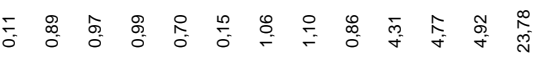
ব

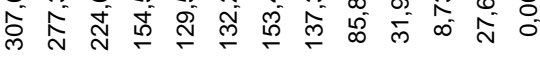

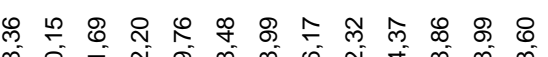

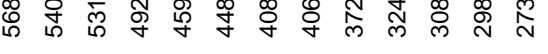

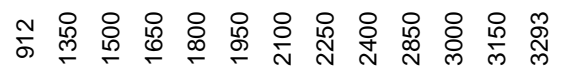

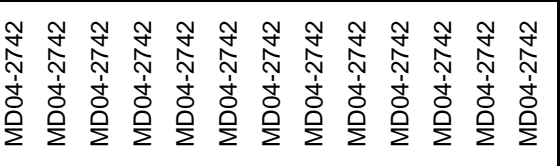




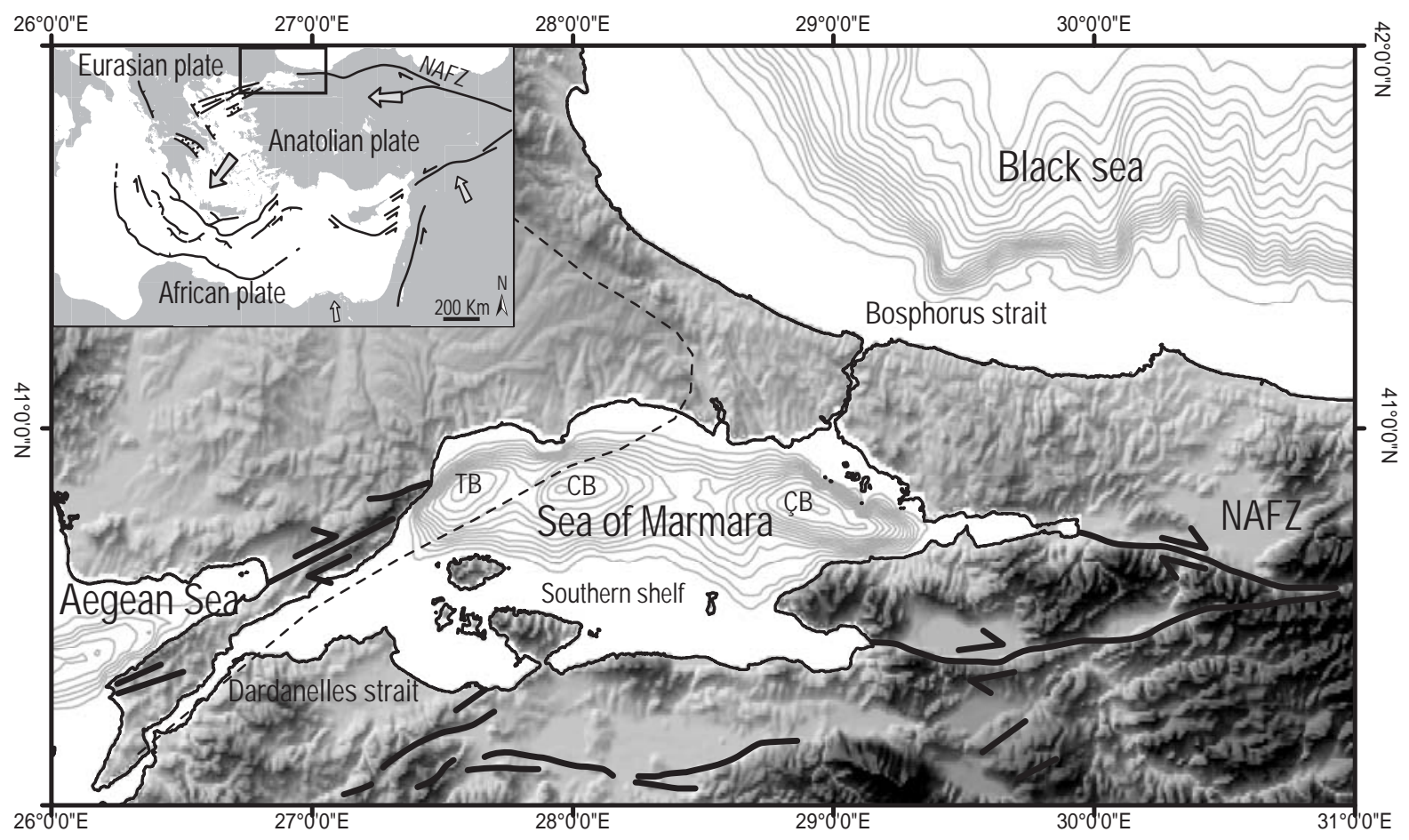




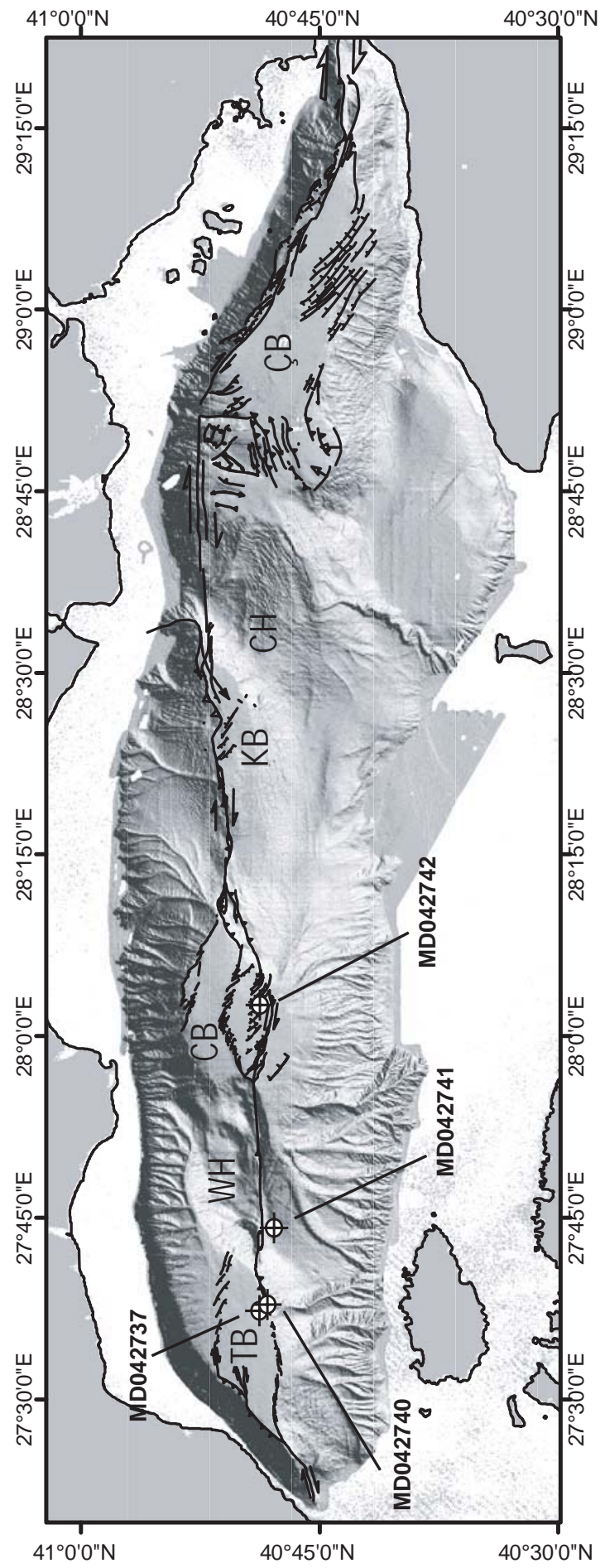




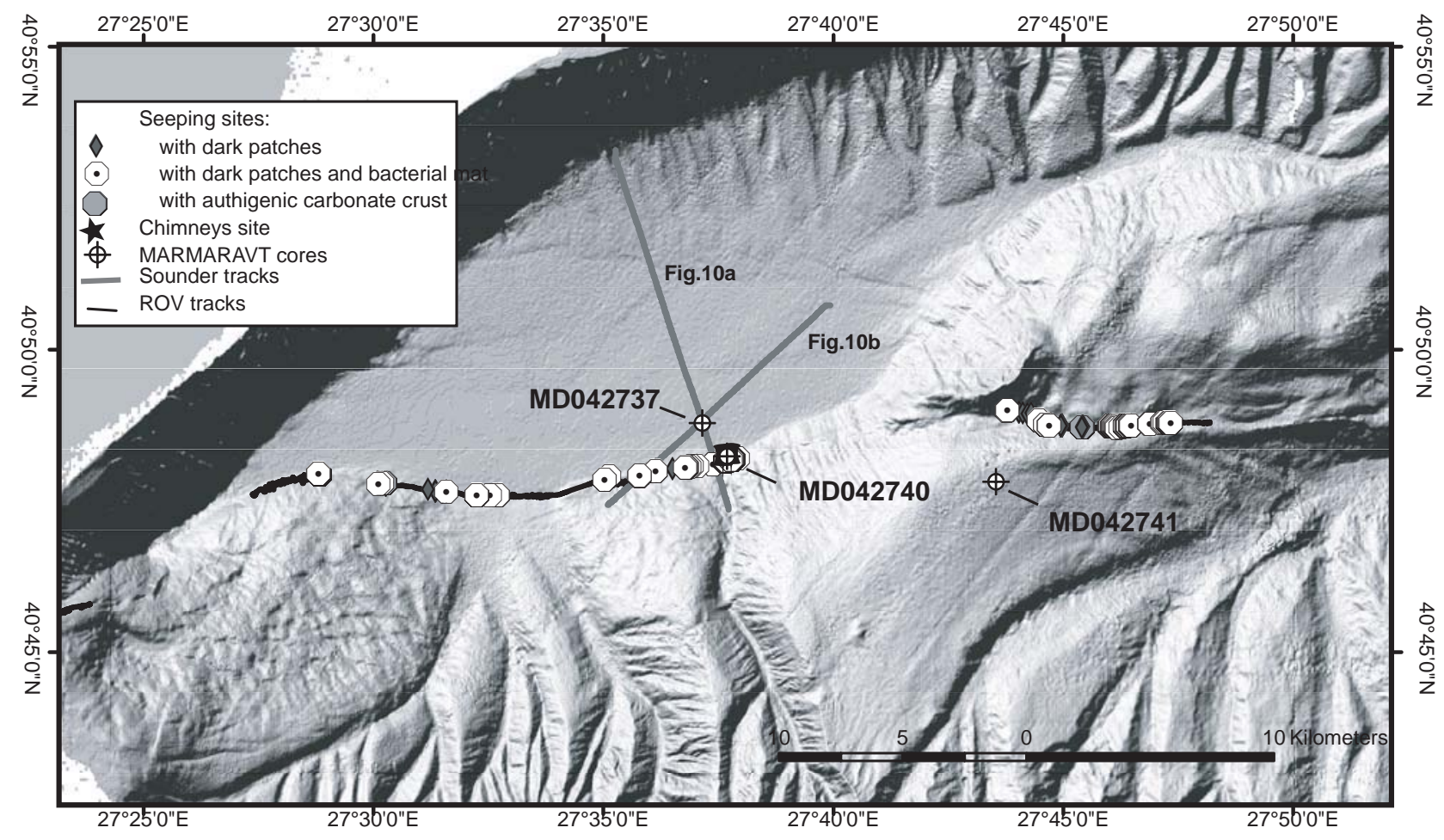




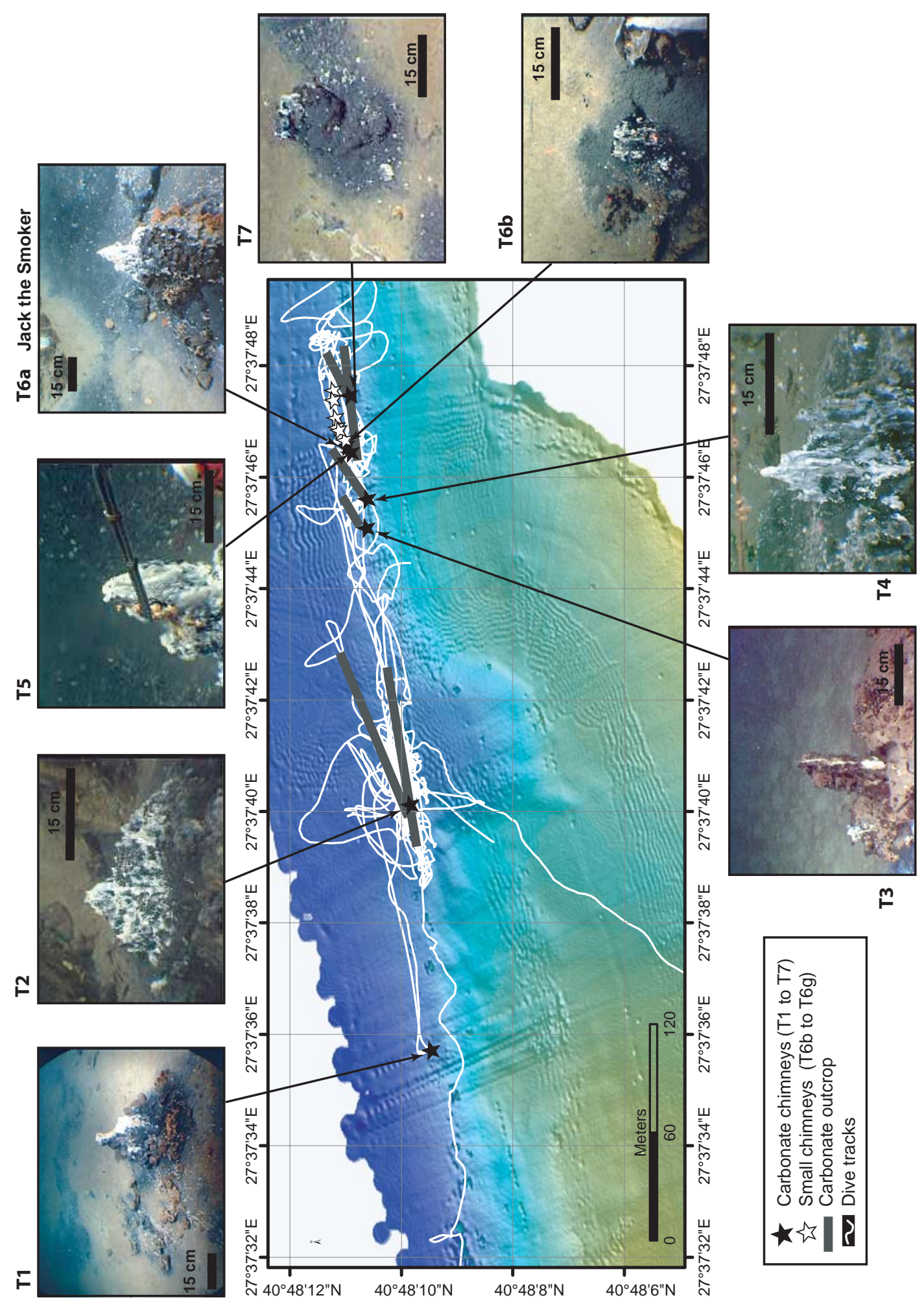



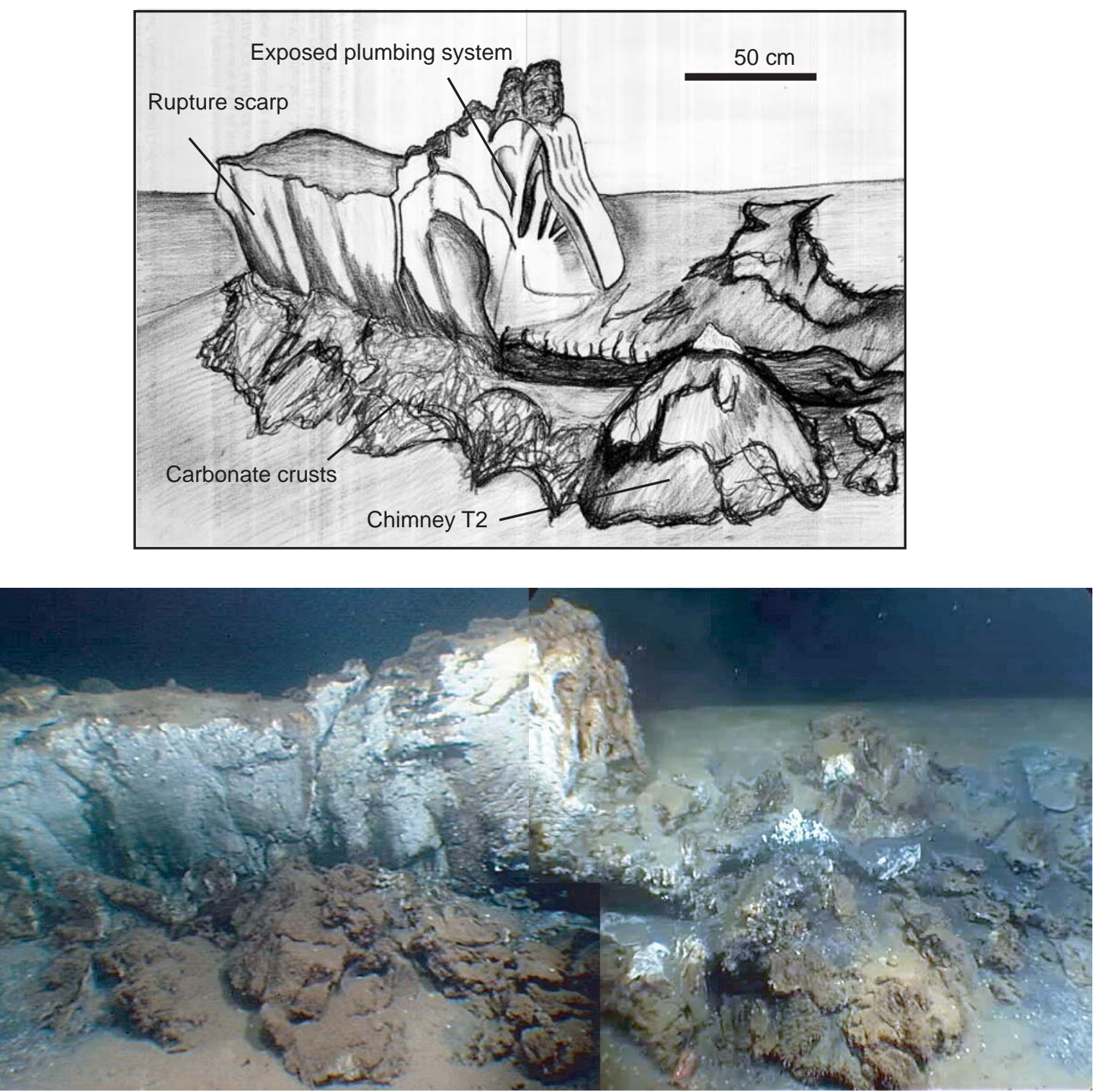


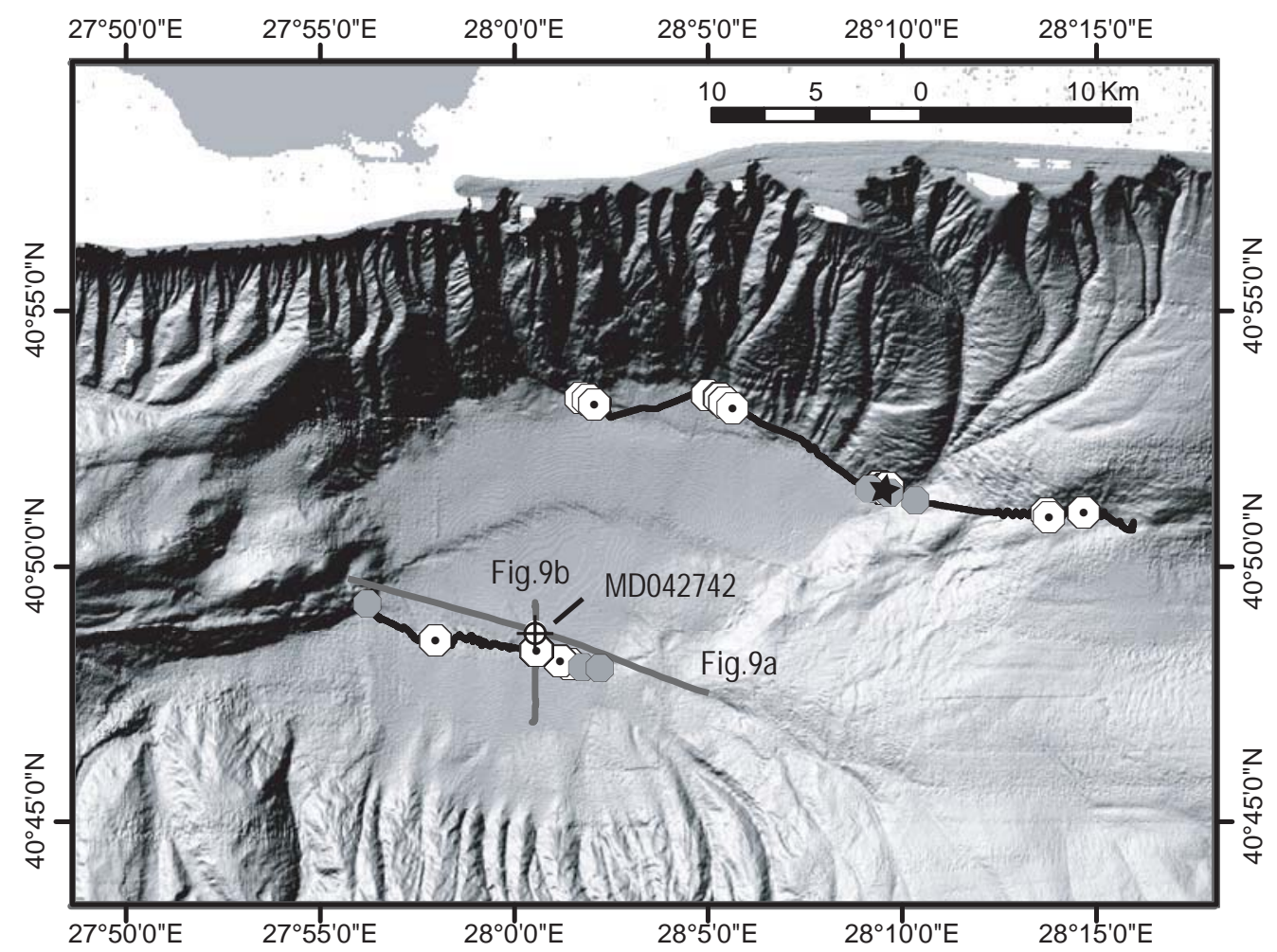




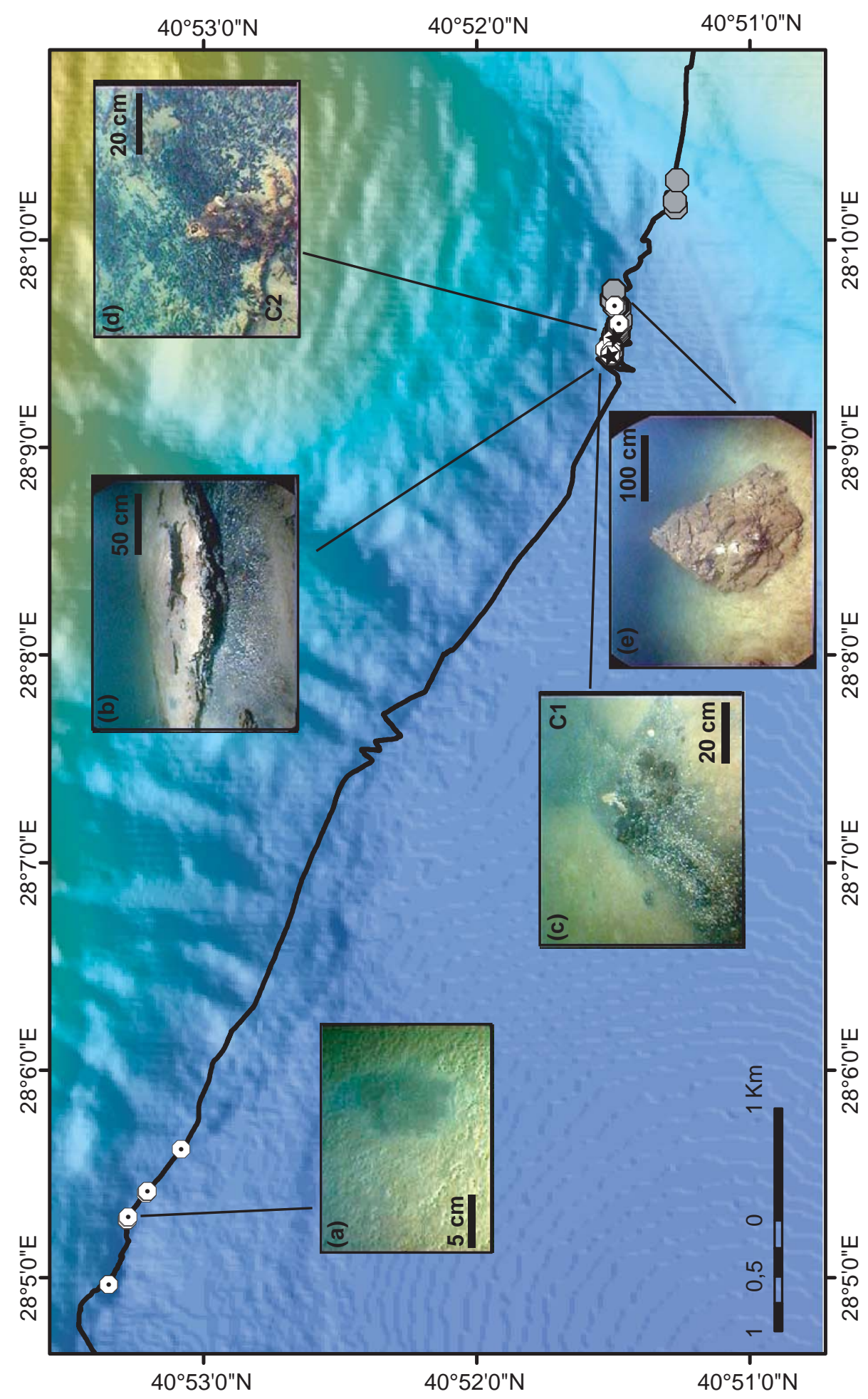




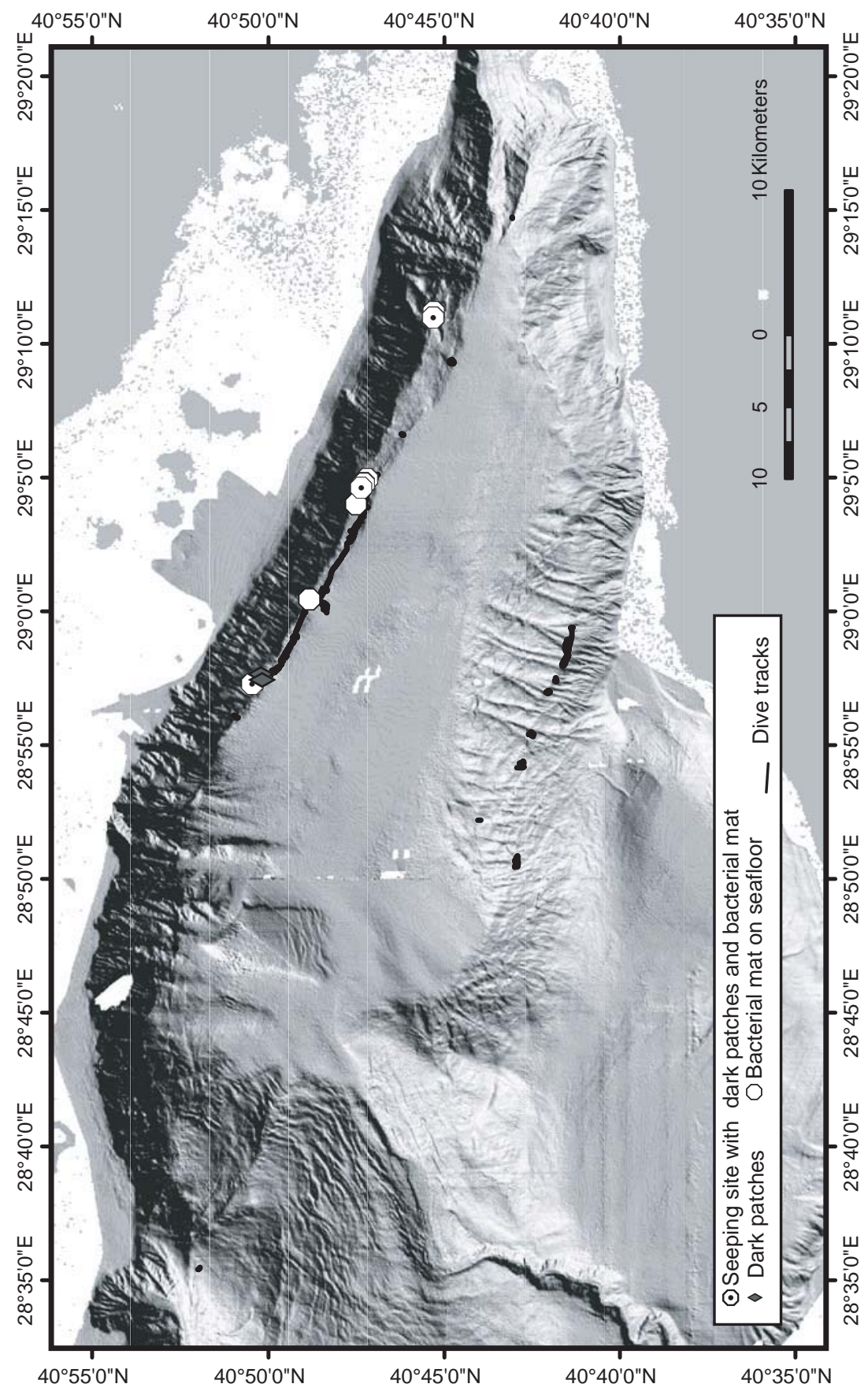



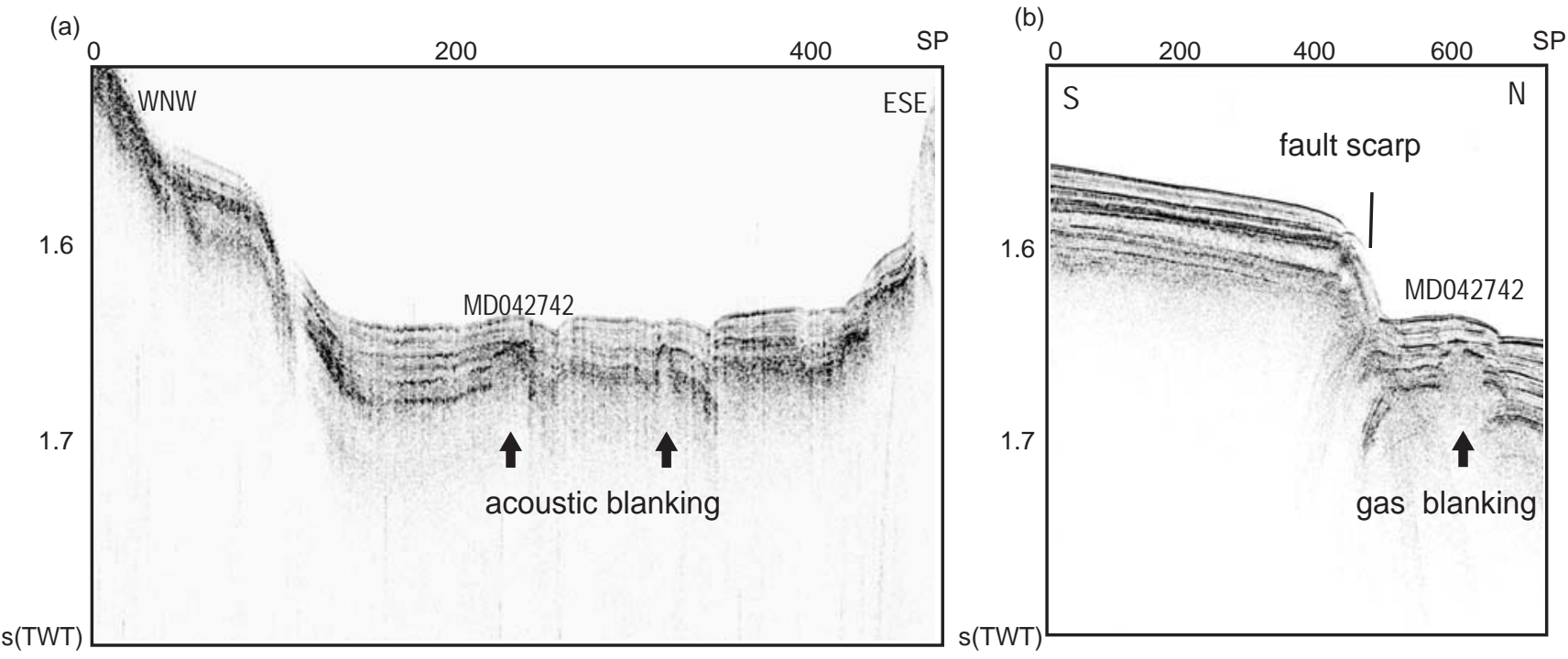


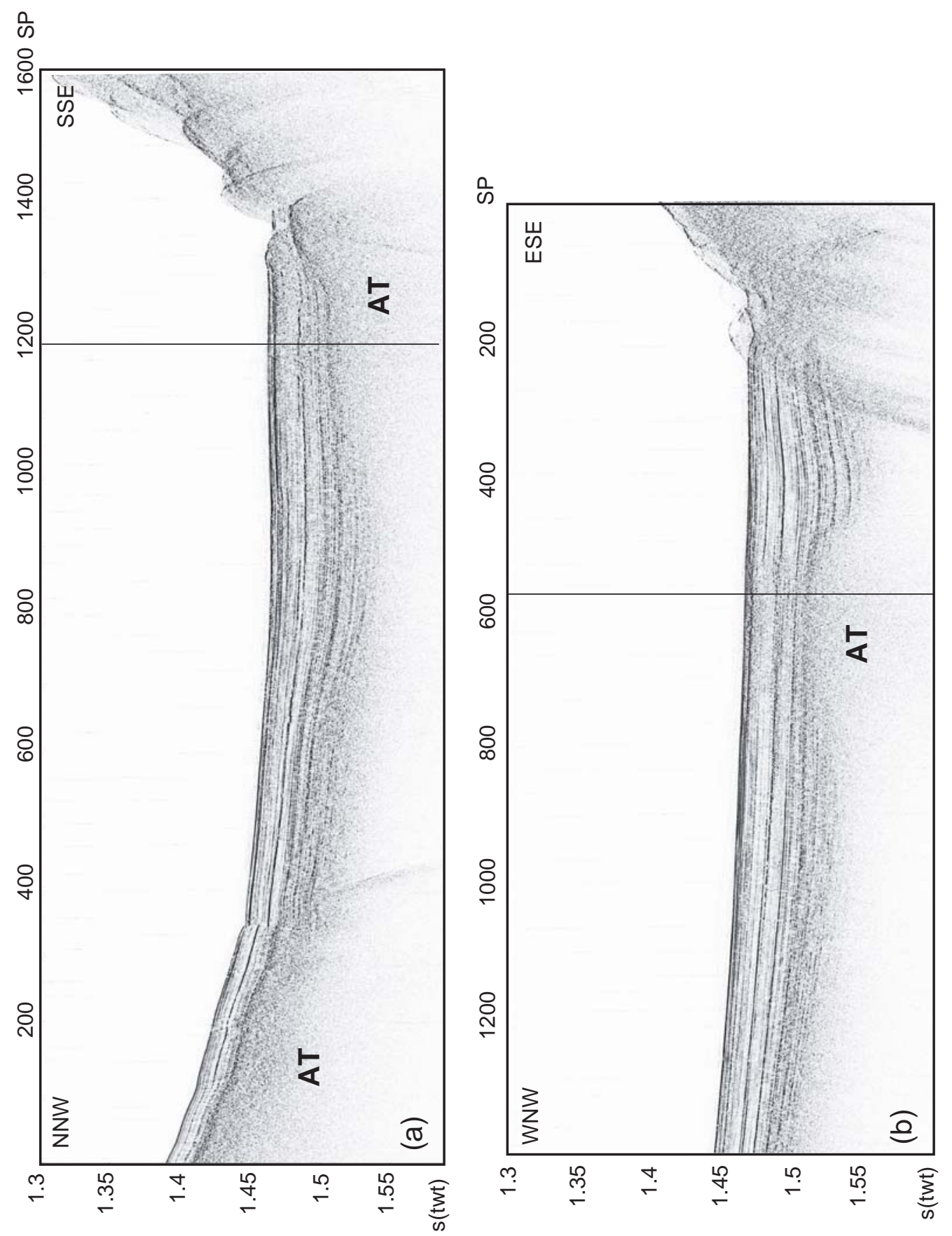



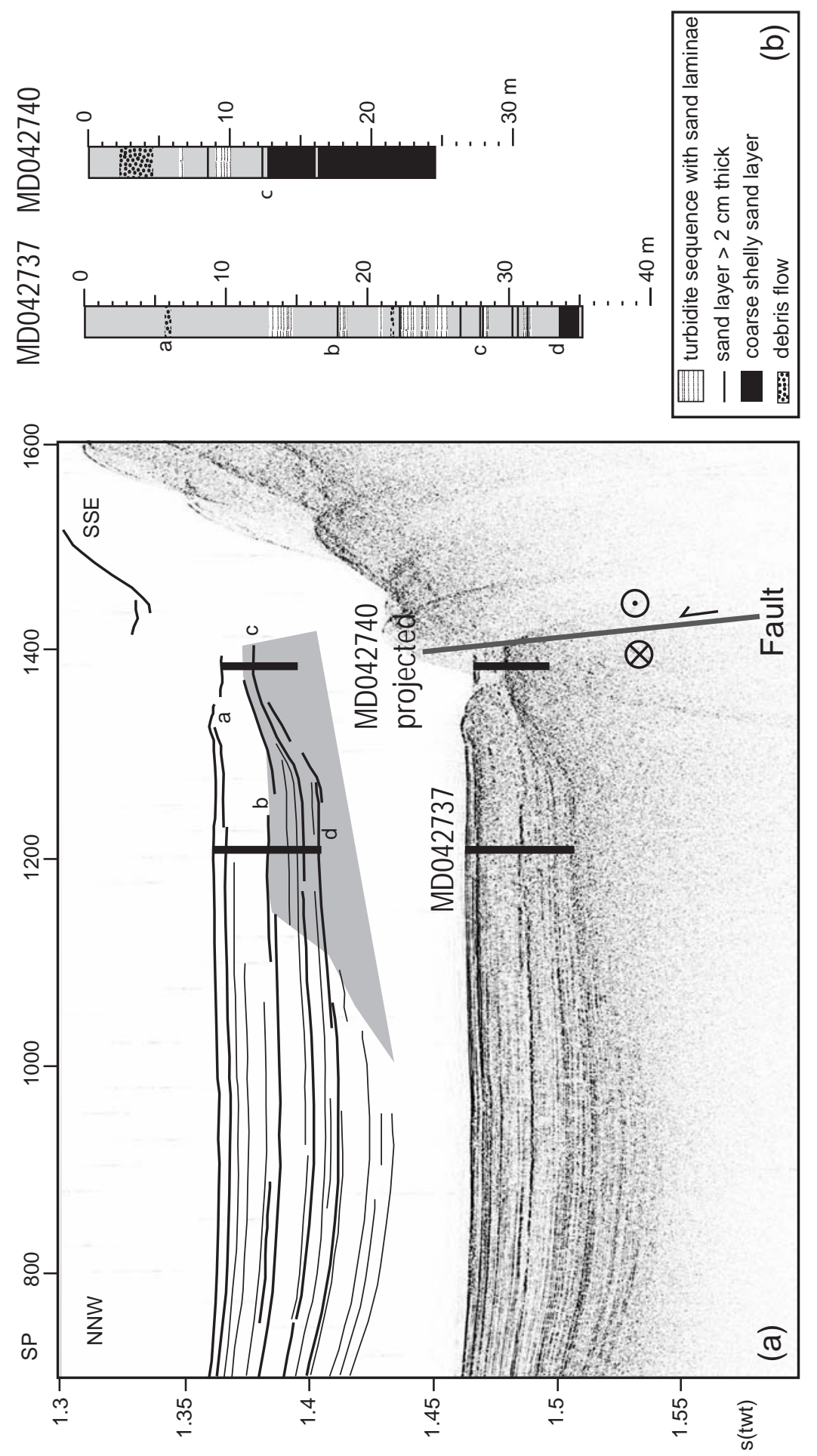


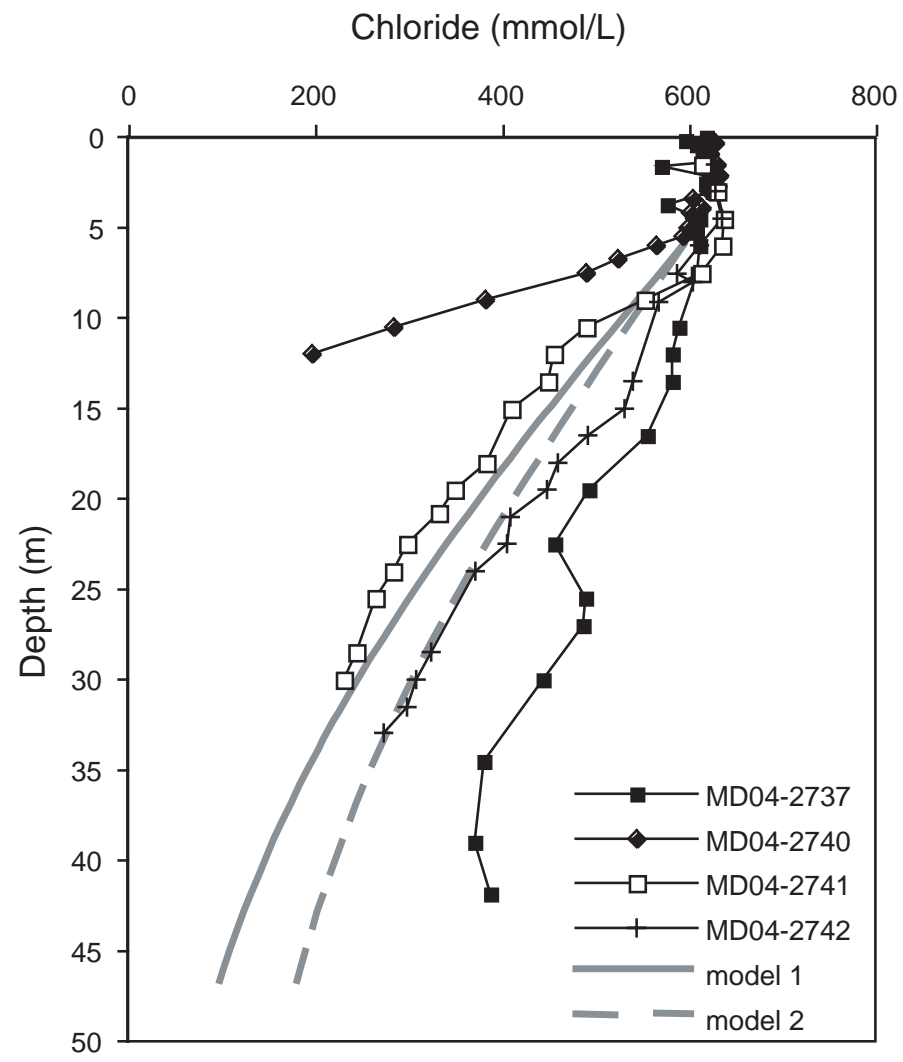



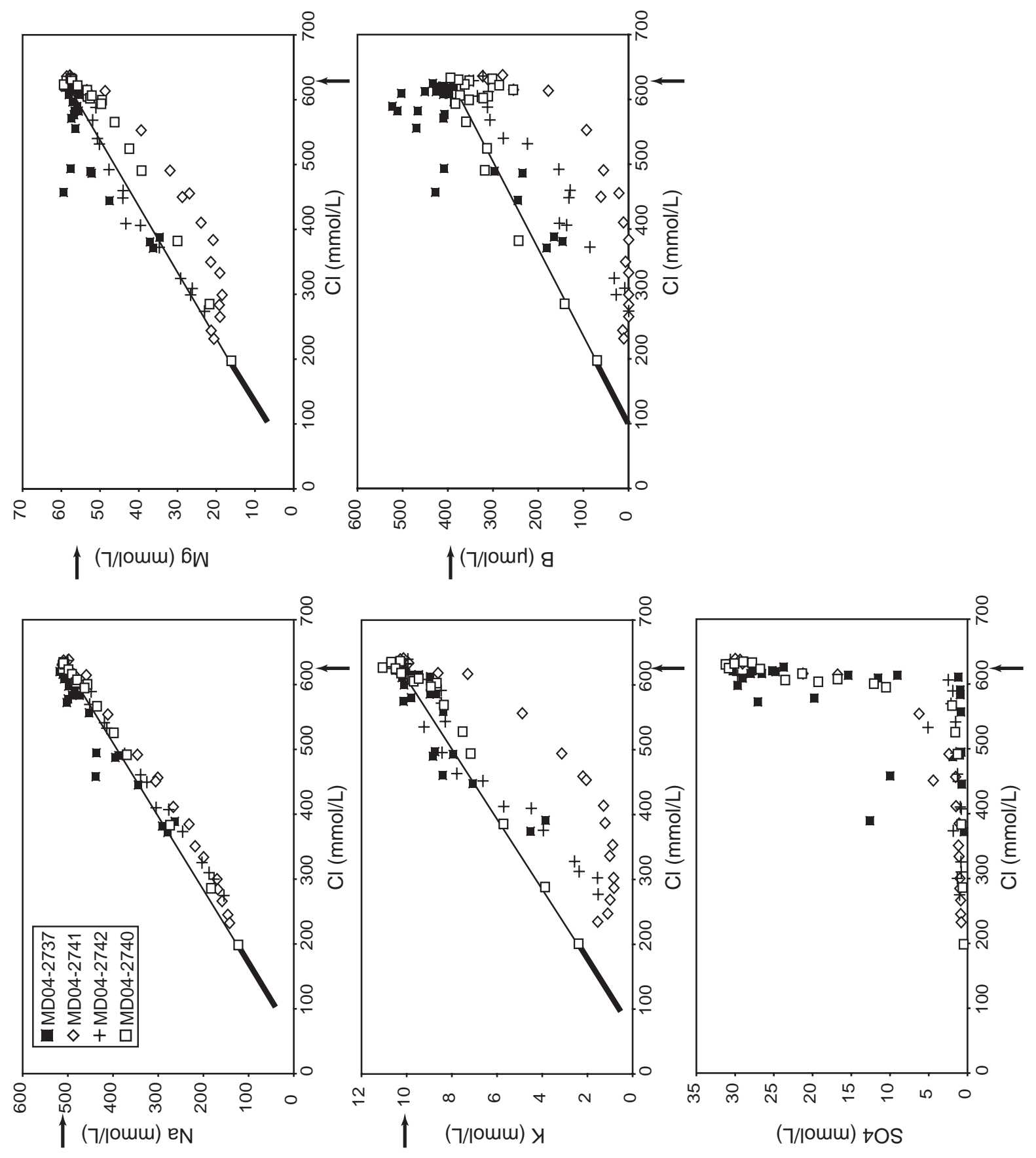


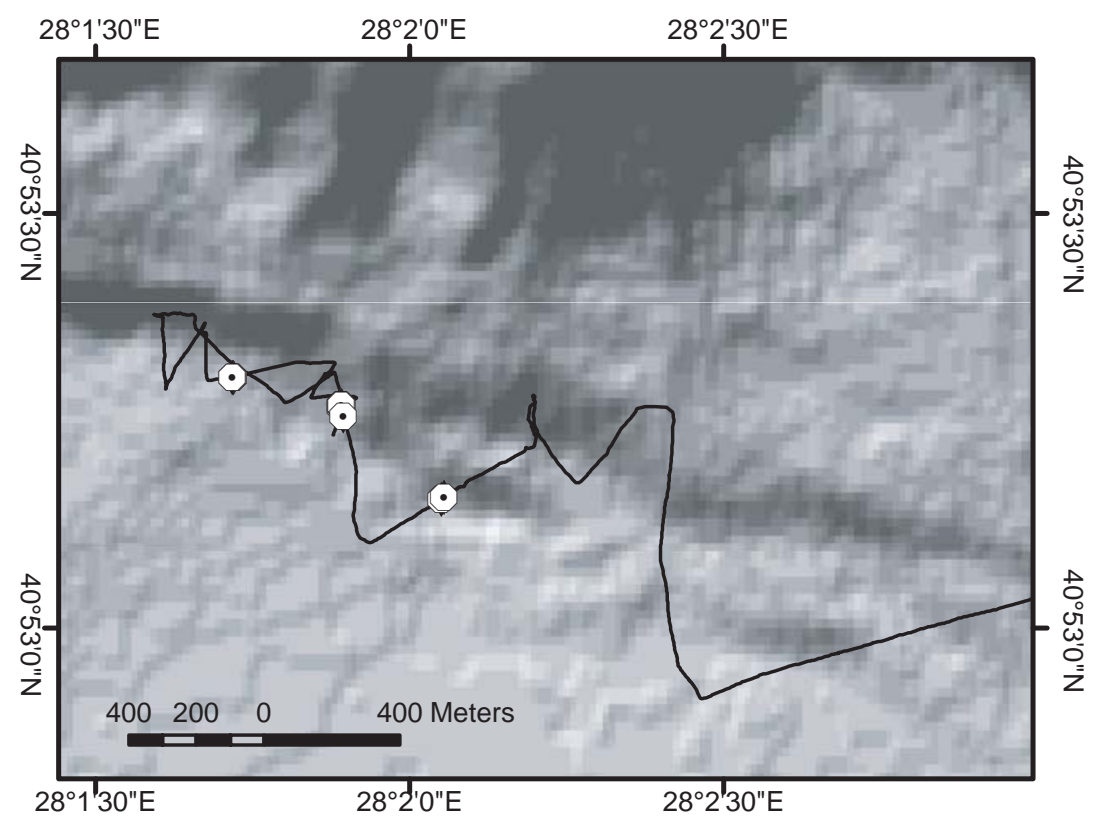

